\title{
Feedbacks between canopy composition and seedling regeneration in mixed conifer broad-leaved forests
}

\author{
S. Catovsky and F. A. Bazzaz
}

\begin{abstract}
Catovsky, S. and Bazzaz, F. A. 2002. Feedbacks between canopy composition and seedling regeneration in mixed conifer broad-leaved forests. - Oikos 98: 403-420.

To address the role of canopy-seedling feedbacks in the structure and dynamics of mixed conifer broad-leaved forests in the eastern US, we monitored seedling regeneration patterns and environmental conditions in the understorey of stands dominated by either hemlock (Tsuga canadensis) or red oak (Quercus rubra) for three years. Hemlock seedlings were favoured over other species' seedlings in hemlock stands (a true positive feedback), due to a combination of high seed inputs, high seedling emergence and relatively high seedling survival during the growing season, which allowed hemlock to remain dominant under its own canopy. Red oak stands favoured a suite of mid-successional broad-leaved species over hemlock. A more even age structure of broad-leaved species in red oak stands revealed that high seedling survival in such stands were driving this feedback. Canopy-mediated variations in both understorey light availability (1.5\% for hemlock vs $3.5 \%$ for red oak) and soil $\mathrm{pH}$ (3.9 for hemlock vs 4.4 for red oak) were found to be the primary correlates of stand-level differences in seedling regeneration dynamics. In mixed temperate forests in the eastern US, canopy-seedling feedbacks could act to slow successional trajectories and contribute to the maintenance of a stable landscape structure over many generations.
\end{abstract}

S. Catovsky and F. A. Bazzaz, Dept of Organismic and Evolutionary Biology, Harvard Univ., 16 Divinity Avenue, Cambridge, MA 02138, USA (present address of SC: NERC Centre for Population Biology, Imperial College at Silwood Park, Ascot, Berks SL5 7PY,UK [fbazzaz@oeb.Harvard.edu]).

It has long been acknowledged that the dynamics of plant communities are driven both by species' responses to their habitat and by species' effects on local environmental conditions (Clements 1916, Horn 1971, Connell and Slatyer 1977). However, in contrast to the many studies addressing species' responses to local environmental conditions, very few studies have directly considered the role played by species' effects on their environment in the structure and dynamics of plant communities (Tilman 1988, Pacala et al. 1996, van Breemen and Finzi 1998). In forest systems, these species' effects may be a particularly important control on community patterns. As canopy trees are large and long-lived, they can substantially influence environmental conditions in the understorey (Boettcher and Kalisz 1990), and thus determine patterns of seedling regenera- tion beneath them (Forcier 1975, Pacala et al. 1996). The influence of canopy trees on understorey conditions varies between species, with the result that canopy composition determines many stand characteristics, including future recruitment patterns (Woods 1984, Cornett et al. 1997).

The strength and direction of interactions between stand composition and seedling regeneration will determine the long-term dynamics of the forest community (e.g. Connell and Slatyer 1977).

1. Negative effects (regeneration of canopy dominants disfavoured). These interactions underlie classical successional seres (Horn 1971), and ultimately produce a shifting mosaic of stand types (Woods 1979, 1984).

Accepted 21 March 2002

Copyright (C) OIKOS 2002

ISSN 0030-1299

OIKOS 98:3 (2002) 
2. Neutral effects (regeneration of no particular species favoured). These interactions produce a null model of species' dynamics, where stochastic events and dispersal patterns drive community patterns (Hubbell and Foster 1986, Hubbell et al. 1999).

3. Positive effects (regeneration of canopy dominants favoured). These interactions create a more persistent landscape structure (Petraitis and Latham 1999), by allowing particular species to maintain dominance of a stand over many generations (Wilson and Agnew 1992).

Canopy-seedling interactions should be particularly important in forest communities composed of distinct stand types (Woods 1979, Hiura and Fujiwara 1999), where species' legacies may be additive and long-lasting (Bazzaz 1983). For example, in mixed conifer broadleaved forests in eastern North America, a positive feedback between canopy composition and seedling regeneration has been proposed as the underlying process controlling the persistence of stands dominated by eastern hemlock (Tsuga canadensis (L.) Carr.) in a matrix of predominantly deciduous, broad-leaved trees (Frelich et al. 1993). In these forests, the distribution of hemlock and broad-leaved stands across the landscape remains relatively stable in the long term (Pastor and Broschart 1990), and does not appear related to any distinct site or disturbance features (Davis et al. 1994, Woods 2000b).

The distinctiveness of hemlock stands in forests in the eastern US has long been recognized (Daubenmire 1930, Oosting and Hess 1956). Compared with most stands dominated by broad-leaved trees, hemlock canopies cast a particularly deep shade (Canham et al. 1994), and produce soils of low $\mathrm{pH}$ and nutrient availability (Finzi et al. 1998a, b). As species differ in their abilities to grow and survive in the forest understorey (Kobe et al. 1995, Walters and Reich 1996), hemlock's alteration of forest floor conditions could significantly influence seedling dynamics in the understorey, and ultimately drive changes in future stand composition. Hemlock seedlings are commonly favoured over broad-leaved tree seedlings in the low resource conditions characteristic of hemlock stands, while the reverse is the case in stands dominated by broad-leaved species (Catovsky and Bazzaz 2000). These interactions set up stand-level positive feedbacks where the presence of a species at a site promotes its continued dominance (Wilson and Agnew 1992, Petraitis and Latham 1999). This notion is similar to Clements (1916) self-perpetuating climax, and supports the view that stability, rather than just disturbance, is an important structuring force in these forests (compare with Oliver and Stephens 1977).

The mechanisms that might lead to such feedbacks and promote landscape stability have not yet been well established. We currently do not know what stages of seedling regeneration are affected by canopy feedbacks, and what particular environmental conditions lead to differential species' responses in the contrasting stand types. To address the role of canopy-seedling feedbacks in the structure and dynamics of mixed conifer broadleaved forests in the eastern US, we monitored components of understorey seedling regeneration dynamics (seed rain, seedling emergence and survival, age structure, long-term seedling persistence) in stands dominated by either hemlock or red oak (Quercus rubra L.), the dominant broad-leaved species in the region (Foster et al. 1998). We then related these seedling dynamics to differences in understorey conditions (light, nitrogen availability, soil moisture, $\mathrm{pH}$, litter depth) in these contrasting stand types. We hypothesized that, because of influences on resource conditions in the understorey, canopy composition favours seedlings of the dominant species (a positive feedback). We predicted that, due to higher resource availability in broad-leaved tree stands than in hemlock stands (especially light, Pacala et al. 1996), seedling emergence, survival, and growth would be higher in oak stands, and the seedling bank would be more even-aged, with a higher proportion of older seedlings. As hemlock is particularly tolerant of understorey conditions (Godman and Lancaster 1990, Kobe et al. 1995), we predicted that these effects would be more pronounced for broad-leaved species than for hemlock, thus creating stand-level positive feedbacks.

\section{Methods}

\section{Details of study sites}

We set up study sites in three hemlock- and three oak-dominated forest stands (each 1-5 ha) at Harvard Forest (Petersham, Massachusetts, USA; 42 $32^{\prime} \mathrm{N}$, $72^{\circ} 11^{\prime} \mathrm{W}$, elevation $340 \mathrm{~m}$ ). The forest is located in the transition hemlock-white pine-northern hardwoods vegetation zone (Spurr 1956, Westveld 1956). The sites were established in the Tom Swamp tract, which has undergone a series of both natural and human disturbances (Oliver and Stephens 1977), most recently the 1938 hurricane (Foster 1988). The sites were chosen so that hemlock and red oak contributed over $50 \%$ of the basal area in each of three stands (Fig. 1). The other major species at the sites were similar between stands, with only four species other than the dominant ever making a significant contribution to stand composition (Acer rubrum L., Betula alleghaniensis Britt., Betula lenta L., Pinus strobus L.). The sites were all located on well-drained loams, and shared many similar physical and biological characteristics (Table 1). There was some variation in past natural and human disturbance, but the patterns were not consistent across stand type, so effects of history were not confounded with the influence of stand composition. 
a)

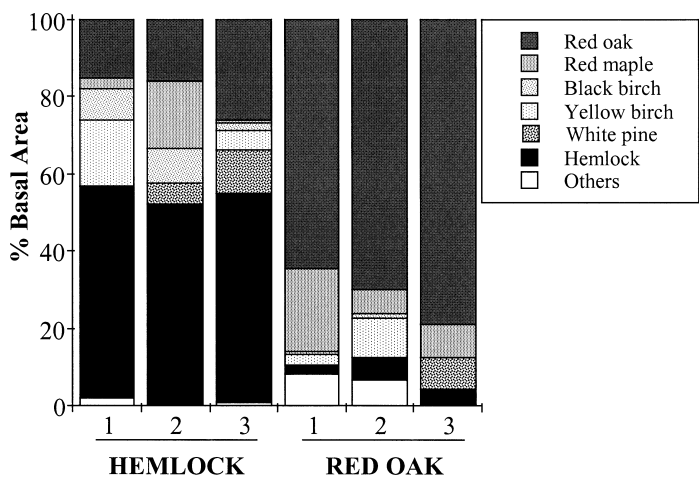

b)

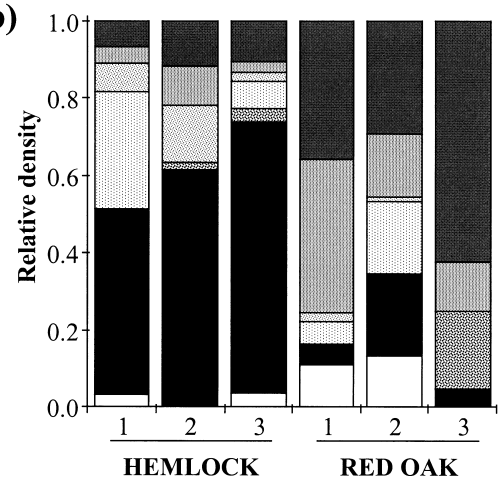

Fig. 1. Canopy tree composition at study sites (three hemlockand three red oak-dominated), expressed as (a) species' contributions to total stand basal area, (b) species' relative density. All trees above $10 \mathrm{~cm}$ diameter at breast height were included, and all species that made more than a $5 \%$ contribution to stand basal area at any one site are shown individually.

\section{Seedling bank dynamics}

At each site, we set up thirty $4 \mathrm{~m}^{2}$ plots $(2 \times 2 \mathrm{~m})$ in a stratified random design. The plots were laid out along three $50 \mathrm{~m}$ transects (each separated by $10 \mathrm{~m}$ ), with one plot positioned randomly within every $5 \mathrm{~m}$ segment of the transect. From June 1997 until September 1999, we took monthly censuses of seedling emergence and survival in all study plots during the growing season. Once they emerged from the seed bank, seedlings were individually labelled with plastic tags inserted into the ground beside them, so that their survival could be monitored in subsequent months (including once after each winter). In addition, in the first growing season, we tagged all seedlings up to $50 \mathrm{~cm}$ tall and monitored their survival over the course of the experiment. Seedlings up to five years old were also aged, based on stem scars formed at the initiation of annual shoot growth. Older seedlings could not be reliably aged, and so were grouped into a single class. At these early growth stages, birch seedlings could not be identified to species, and thus demographic data were collected to the genus level (Betula) only in these cases.

Seed rain into the plots for the 1998 and 1999 field seasons was measured from seed traps placed beside each seedling plot (30 per site). Seed traps were constructed as inverted muslin cones (opening $0.2 \mathrm{~m}^{2}$ ) suspended $50 \mathrm{~cm}$ above the forest floor with a PVC frame (modified from Hughes et al. 1987). In 1997 and 1998, seed traps were emptied in July (for red maple seeds) and then monthly from September to December. For some species (oak, maples), we were able to distinguish filled vs empty seeds, and we only recorded filled seeds. For hemlock and the birch species, we counted all seeds and then sub-sampled to look at the percentage of seeds filled $(65 \%$ for hemlock, $85 \%$ for yellow and black birch, $75 \%$ for white and grey birch species). Seed rain in 1997 and 1998 was then used in combination with seedling emergence in 1998 and 1999 to calculate proportional seedling emergence, based on the assumption of no seed bank for any of these species. This assumption should be reasonable as only a very small fraction of seeds of our study species will remain viable past their first growing season (Burns and Honkala 1990).

Table 1. Stand characteristics of study sites (three hemlock- and three red oak-dominated), obtained from field measurements and from the Tom Swamp map series (Harvard Forest Archives). Current canopy composition for each site is shown in Fig. 1.

\begin{tabular}{|c|c|c|c|c|c|c|}
\hline \multirow{2}{*}{$\begin{array}{l}\text { Stand } \\
\text { characteristics }\end{array}$} & \multicolumn{3}{|c|}{ Hemlock } & \multicolumn{3}{|c|}{ Red oak } \\
\hline & 1 & 2 & 3 & 1 & 2 & 3 \\
\hline Soil Type & Brookfield loam & Brookfield loam & Brookfield loam & Brookfield loam & $\begin{array}{l}\text { Montauk fine } \\
\text { sandy loam }\end{array}$ & Brookfield loam \\
\hline Drainage & Well drained & Well drained & Well drained & Well drained & Well drained & Well drained \\
\hline Slope/Aspect & $5^{\circ} \mathrm{NE}$ & $7^{\circ} \mathrm{NW}$ & $4^{\circ} \mathrm{N}$ & $4^{\circ} \mathrm{W}$ & $4^{\circ} \mathrm{S}$ & $7^{\circ} \mathrm{N}$ \\
\hline Elevation (m) & 820 & 790 & 820 & 870 & 870 & 780 \\
\hline Density $^{\mathrm{a}}\left(\mathrm{ha}^{-1}\right)$ & 1190 & 600 & 840 & 980 & 750 & 1450 \\
\hline $\begin{array}{l}\text { Total basal areaa } \\
\left(\mathrm{m}^{2} \mathrm{ha}^{-1}\right)\end{array}$ & 42.4 & 39.8 & 47.2 & 38.4 & 37.2 & 42.8 \\
\hline $\begin{array}{c}1938 \text { hurricane } \\
\text { damage }(\%)\end{array}$ & $15-25$ & $0-10$ & $80-90$ & $90-100$ & $0-10$ & $60-70$ \\
\hline $\begin{array}{l}\text { Land use in } \\
1850^{\mathrm{b}}\end{array}$ & Farm & Farm & Woodlot & Woodlot & Farm & Meadow \\
\hline
\end{tabular}

${ }^{\text {a }}$ For all trees greater than $10 \mathrm{~cm} \mathrm{DBH}$.

${ }^{\mathrm{b}}$ From Raup and Carlson (1941). 


\section{Environmental measurements}

Above- and below-ground resource availability in each plot was determined using methods and sampling protocols that would provide a good indication of integrated plant-available resources. Light availability was measured using two independent techniques: (1) stacked light-sensitive diazo paper (Friend 1961), and (2) quantum sensors placed above and below the canopy on a uniformly overcast day to give a good estimate of mean daily\% photon flux density (PFD) (Parent and Messier 1996). In July 1997, stacks of diazo paper $(1 \times 2 \mathrm{~cm}$, ten sheets thick) were placed horizontally on stakes at $5 \mathrm{~cm}$ and $1 \mathrm{~m}$ above the ground in each plot. After five days of exposure, the stacks were developed in ammonia vapour. Simultaneously, we set up a calibration with identical diazo paper stacks exposed for different lengths of time under another forest canopy, using a leveled Li-Cor LI-190SA quantum sensor attached to LI-1000 data-logger (Li-Cor, Lincoln, Nebraska, USA) to measure moles of light received for each time interval. This calibration (cumulative photons received vs layers of paper penetrated, $r^{2}=0.98$ ) was then used to calculate moles of light received by each stack of diazo paper in the plots.

On a uniformly overcast day in July 1999, the same quantum sensor and data-logger combination was placed on the top of one of the canopy access towers at Harvard Forest and set to record instantaneous PFD (measured every second and averaged over one minute intervals). We used a second quantum sensor (leveled each time) and data-logger combination to record PFD beneath the canopy at each of our $2 \times 2 \mathrm{~m}$ demography plots (at $5 \mathrm{~cm}$ and $1 \mathrm{~m}$ ). Data-loggers were synchronized and the data were used to calculate percent PFD transmitted through the canopy above each plot.

Nitrogen availability in each plot was also measured using two techniques: (1) in situ buried bags to calculate mineralization rates (Pastor et al. 1984), and (2) ion exchange resin bags to determine season-long integrated availability of ammonium and nitrate (Gibson 1986). In July 1997, two organic horizon soil cores (10 $\mathrm{cm}$ diameter, 5-15 $\mathrm{cm}$ deep) were collected from the edge of each $2 \times 2 \mathrm{~m}$ plot. One core of each pair was brought back to the lab soon after extraction, while the second was placed in a polyethylene bag surrounded by mesh and buried in the organic horizon at each plot until the end of August that year. For each core (initial and incubated) $10 \mathrm{~g}$ of sifted soil $(5.6 \mathrm{~mm}$ mesh) was extracted with $100 \mathrm{ml}$ of $2 \mathrm{~N}$ potassium chloride solution $\left(25^{\circ} \mathrm{C}, 48\right.$ hours $)$, and then frozen immediately following suction-filtration. Extracts were analyzed for ammonium and nitrate ion concentrations on a Technicon TRAACS 800 analyzer (Braun and Luebbe, Buffalo Grove, Illinois, USA). Ammonium was measured using the Berthelot Reaction chemistry (Method No. 780-86T) and nitrate was measured using hydrazine sulphate reduction (Method No. 782-86C). Detection limit for both these methods was $0.2 \mathrm{mg}^{-1}$. Water content of each soil sample was determined by weighing $2-3 \mathrm{~g}$ of soil before and after oven drying $\left(105^{\circ} \mathrm{C}, 72\right.$ hours), so that nutrient availability could be expressed per $g$ dry soil.

In 1999, ion exchange resin bags were placed in the field from early June until late October. The bags were constructed with 1.5 tablespoons $(22 \mathrm{ml})$ of mixed bed strong acid (cation) and strong base (anion) gel resins (Sybron Chemicals, Birmingham, New Jersey, USA) sealed in nylon mesh, and placed at a depth of $5 \mathrm{~cm}$ in the soil. After removal from the soil, $4 \mathrm{~g}$ of dried resin $\left(70^{\circ} \mathrm{C}\right.$, overnight) was extracted with $100 \mathrm{ml}$ of $2 \mathrm{~N}$ potassium chloride solution $\left(25^{\circ} \mathrm{C}, 24\right.$ hours $)$, and then frozen immediately following suction-filtration. Ammonium and nitrate in all resin extracts were measured using a LaChat continuous flow ion analyzer using methods 12-107-06-1-A and 12-407-04-1-B (LaChat Instruments, Milwaukee, Wisconsin). Blanks were created from resin bags that had been sealed in polyethylene bags for the length of the growing season. These resins were used to determine the lower threshold of detection.

Water availability was determined at three times during the 1997 and 1999 growing seasons and averaged to give full season integrated estimates. At each time, soil cores from both organic $(10 \mathrm{~cm}$ diameter, $5-10 \mathrm{~cm}$ deep) and mineral $(2 \mathrm{~cm}$ diameter, $20 \mathrm{~cm}$ deep) horizons were taken from the edge of each plot. Sieved soil (5.6 mm mesh for organic, $2 \mathrm{~mm}$ mesh for mineral) was dried $\left(105^{\circ} \mathrm{C}, 48\right.$ hours $)$ to determine gravimetric water content. These values were expressed on a volumetric basis using bulk density measurements ( $0.12 \mathrm{~g} \mathrm{~cm}^{-3}$ for organic, $0.70 \mathrm{~g} \mathrm{~cm}^{-3}$ for mineral) taken at each study site, but then pooled across sites as there were no significant differences between sites $\left(\mathrm{F}_{4,30}=1.88\right.$ for organic and 0.16 for mineral, both $\mathrm{p}>0.05)$.

In 1998, soil $\mathrm{pH}$ for the organic horizon was measured from $10 \mathrm{~cm}$ diameter soil cores (depth 4-12 cm). $\mathrm{pH}$ of sieved soil (5.6 mm mesh) was measured on a mixture of $2 \mathrm{~g}$ of air-dried soil in $20 \mathrm{ml}$ distilled water (pH 5.5) using an Orion 250A pH meter (Orion Instruments, Boston, Massachusetts). In the same year, depth of the litter layer and the organic horizon were measured in each plot using a trowel to gently expose the upper layers of the soil profile. At the end of the year, litter collected in seed traps (described in previous section) was dried $\left(70^{\circ} \mathrm{C}, 100\right.$ hours), and coniferous and broad-leaved litter types were sorted and weighed.

\section{Statistical analysis}

Multi-factor analyses of variance (ANOVA) were used to investigate seedling regeneration dynamics in the 
a) 1997

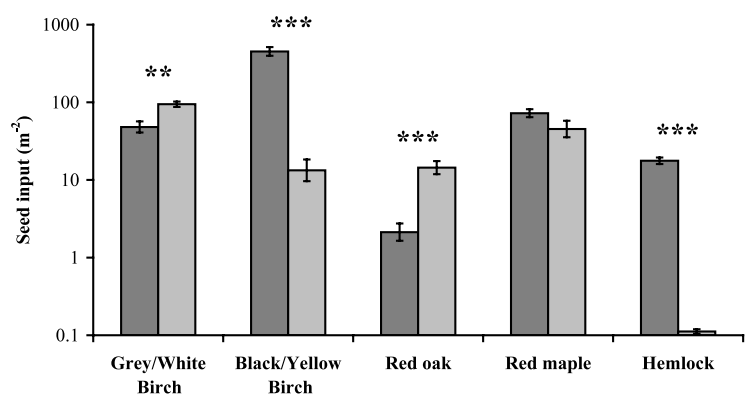

b) 1998

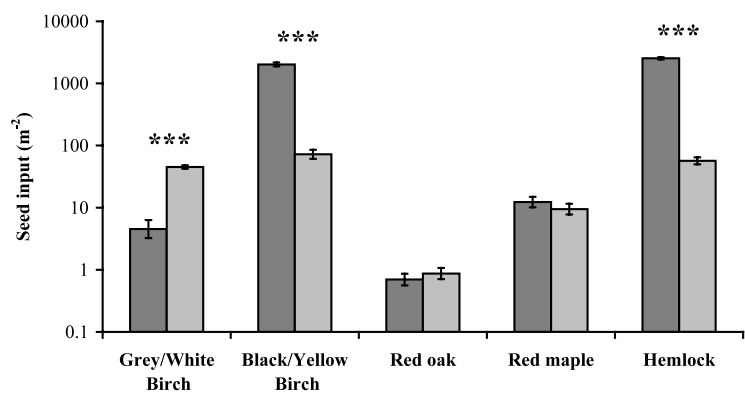

Fig. 2. Annual seed rain inputs (mean \pm 1 SEM) in hemlock ( $\square$ ) and red oak ( $\square$ ) stands (viable seeds only). Means and standard errors were calculated from log transformed data at the plot level $(n=90)$ and then back-transformed, and are shown for the two seed rain measurement years separately (a b). Note $\log$ scale of y-axis. Means that were significantly different between stand types are marked with asterisks $\left(^{*} \mathrm{p}<\right.$ $0.05, * * \mathrm{p}<0.01,{ }^{* * *} \mathrm{p}<0.001$, based on Bonferroni comparisons).

forest understorey. We constructed full interaction linear models with a variety of fixed, discrete factors (stand type, species, year) and occasional continuous factors (e.g. seedling age). Models also included a nested series of random factors (site nested within stand, and plot nested within site). Since we were most interested in comparing species' regeneration patterns in different stand types, any significant interactions involving species $\times$ stand interactions were investigated further using sequential Bonferroni corrected planned contrasts to test for differences in species' responses between hemlock and red oak stands (Sokal and Rohlf 1995).

When necessary, data were transformed to ensure that the assumptions of analysis of variance were met (normality of residuals, homoscedascity). Common transformations included natural logarithm (seed rain, emergence, abundance, age, biomass) and the logit function (proportional survival). Presence/absence of older seedlings ( $>5$ yrs old) in study plots was examined using the non-parametric Mantel-Haenszel test (Sokal and Rohlf 1995), as logistic models did not converge. We initially tested for homogeneity between sites (no significant difference between sites for any species) and then combined data from all the sites within one stand type to make pairwise treatment comparisons.

Relationships between seedling dynamics and environmental variables were investigated with stepwise multiple regression models (Sokal and Rohlf 1995), including year and species as fixed discrete factors, and site as a random discrete factor. Stand type was replaced in the model with a suite of environmental variables (continuous factors). Each model began with the same set of environmental factors - \% photon flux density (PFD) at ground level, availability of soil ammonium and nitrate from ion exchange resin bags, $\mathrm{O}$ horizon volumetric water content averaged over 1997 and 1999 (consistency between years, $\mathrm{r}_{180}=0.85, \mathrm{p}<$ 0.05 ), soil $\mathrm{pH}$, and litter depth. These measurements were chosen to give a good indication of a seedling's eye-view of local environmental conditions. Variables that explained little of the variance in the model were removed in a stepwise manner. Significant species $\times$ environment interactions in the models were further investigated by examining significance of standardized partial regression coefficients for individual species. Certain species were excluded from some analyses due to lack of data - white pine from proportional emergence analysis, red oak from survival analysis, and hemlock from age structure analysis.

\section{Results}

\section{First-year regeneration dynamics}

Only five species made any significant contribution to the understorey seedling bank at our study sites: birch (Betula spp.), red maple (Acer rubrum), red oak (Quercus rubra), white pine (Pinus strobus), and eastern hemlock (Tsuga canadensis). During seed rain measurement years (1997, 1998), seed inputs of all species except white pine were recorded (Fig. 2). White pine had a large seed production year the previous year (Catovsky and Bazzaz 2000). Hemlock, red maple, red oak and grey/white birch (seeds could not be distinguished) all had larger seed production years in 1997, while seed production of black/yellow birch was larger in 1998. Patterns of species' seed inputs differed between both stand types and years of study (significant species $\times$ stand $\times$ year interaction, $F_{4,1602}=13.32, p<$ $0.001)$. Red maple seed inputs did not differ between stand types, while both hemlock and black/yellow birch had between 30 and 150 times greater seed inputs in hemlock stands than in red oak stands (Fig. 2). In contrast, grey/white birch and red oak (1997) had significantly higher seed inputs in red oak stands than in hemlock stands.

Species exhibited differential seedling emergence from the soil seed bank in contrasting stand types, and 
these effects varied between years of study (significant species $\times$ stand $\times$ year interaction, $F_{3,1009}=12.36, p<$ $0.001)$. For birch and hemlock, not only were seed inputs greater in hemlock stands than in red oak stands, but proportional emergence of the seeds that arrived was also greater (Fig. 3), with birch having $0.5 \%$ emergence in hemlock stands compared with $0.0075 \%$ in red oak stands, and hemlock having $1.2 \%$ and $0.0005 \%$ (respectively). The larger seeded species, red maple and red oak, did not differ in proportional emergence between hemlock and oak stands (Fig. 3).

This variation in seed input and proportional emergence from seed led to overall species' differences in total seedling emergence from the soil seed bank in contrasting stand types, and again these effects varied between years of study (significant species $\times$ stand $\times$ year interaction, $\left.\mathrm{F}_{8,2496}=28.35, \mathrm{p}<0.001\right)$. Both birch and hemlock consistently showed greater total emergence in hemlock stands than in red oak stands (Fig. 4), with a 30- to 70-fold increase for birch, and a 2- to 2000-fold increase for hemlock. Emergence of white pine seedlings was also significantly greater in hemlock stands than in red oak stands, but only in 1997, which was the only seed production year for white pine during

a) 1998

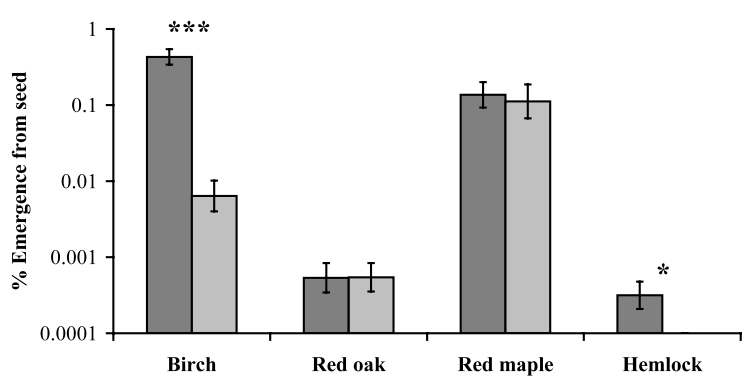

b) 1999

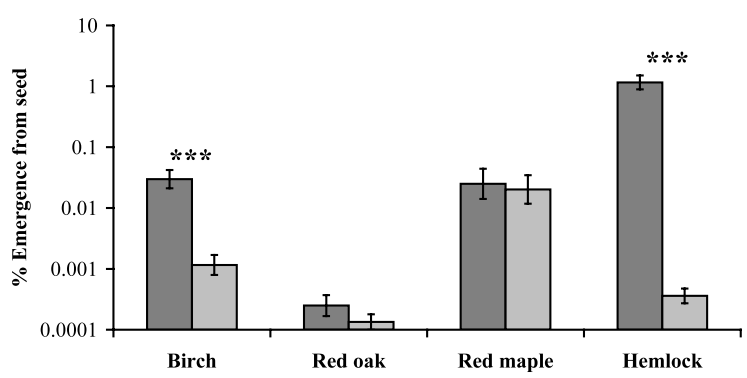

Fig. 3. Proportional seedling emergence (mean \pm 1 SEM) from the previous year's seed inputs in hemlock $(\square)$ and red oak $(\square)$ stands. Means and standard errors were calculated from log transformed data at the plot level $(\mathrm{n}=37-90)$ and then backtransformed, and are shown separately for each year for which the previous year's seed rain data were available $(a, b)$. Note log scale of y-axis. Means that were significantly different between stand types are marked with asterisks $(* \mathrm{p}<0.05, * * \mathrm{p}<0.01$, $* * * \mathrm{p}<0.001$, based on Bonferroni comparisons). a) 1997

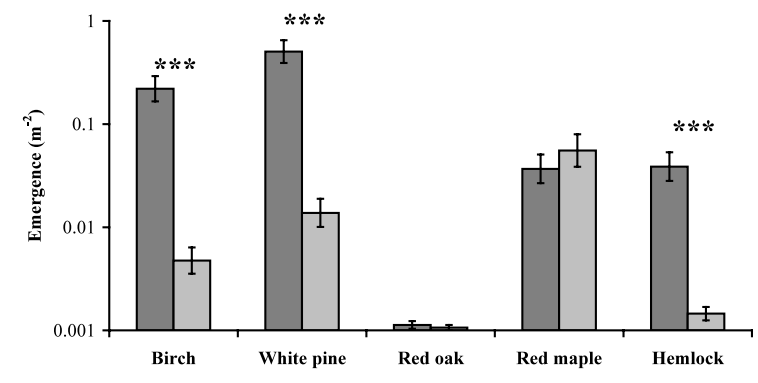

b) 1998

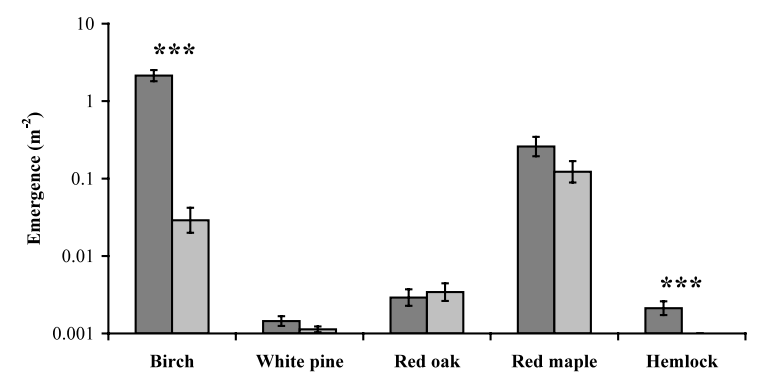

c) 1999

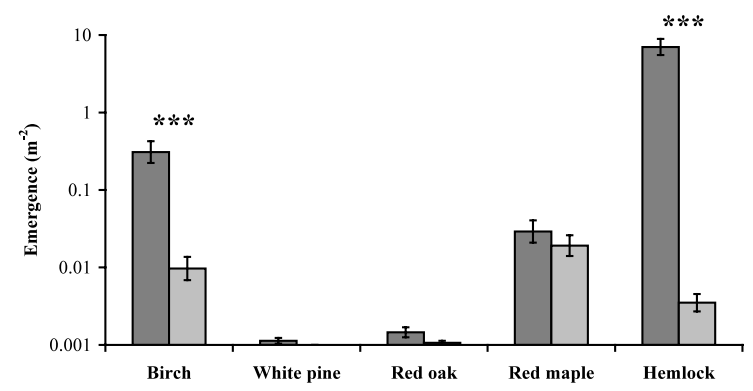

Fig. 4. Total seedling emergence (mean \pm 1 SEM) from the soil seed bank in hemlock $(\square)$ and red oak $(\square)$ stands. Means and standard errors were calculated from log transformed data at the plot level $(n=90)$ and then back-transformed, and are shown for each year of study separately $(a-c)$. Note log scale of y-axis. Means that were significantly different between stand types are marked with asterisks $\left({ }^{*} \mathrm{p}<0.05,{ }^{* *} \mathrm{p}<0.01,{ }^{* * *} \mathrm{p}<\right.$ 0.001 , based on Bonferroni comparisons).

the course of the study (see above). Given the lack of variation in seed inputs and proportional emergence, red oak and red maple seedlings showed no difference in total emergence between the stand types in any year (Fig. 4).

Similarly, species' first-year survival differed between stand types and study years (significant species $\times$ stand $\times$ year interaction, $\left.F_{6,817}=5.13, p<0.001\right)$. Red maple consistently had significantly higher seedling survival in red oak stands $(25-85 \%)$ than in hemlock stands (1-2.5\%) (Fig. 5). In 1997 and 1998, birch also had significantly higher survival in red oak stands $(6-8 \%)$ than in hemlock stands $(0.25-0.75 \%)$. Red oak 
had the highest first year survival (close to $100 \%$ each year) of all the species, and only underwent a significant reduction in survival in hemlock stands in 1999 (Fig. 5). Neither hemlock nor white pine showed any significant differences in survival between hemlock and red oak stands, although there was a tendency for survival to increase for white pine in red oak stands and decrease for hemlock.

Patterns of seedling emergence and survival were reflected in species-specific seasonal changes in seedling abundance that differed between stand types, and to

a) 1997

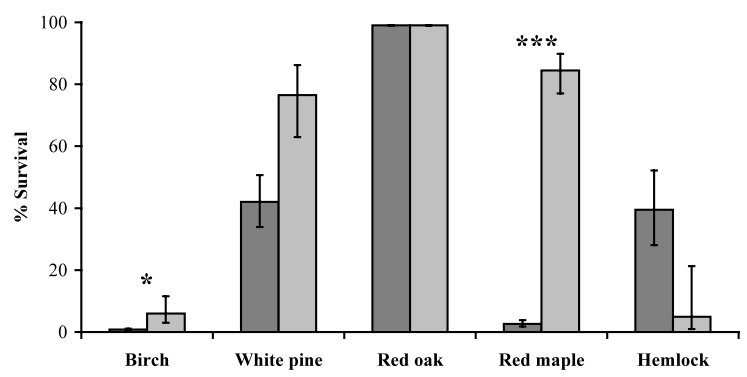

b) 1998

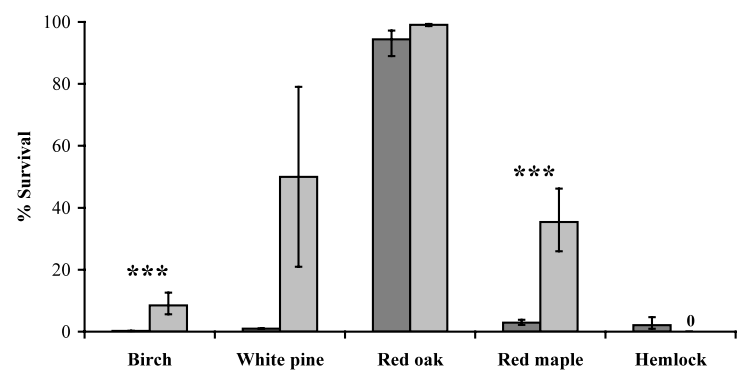

c) 1999

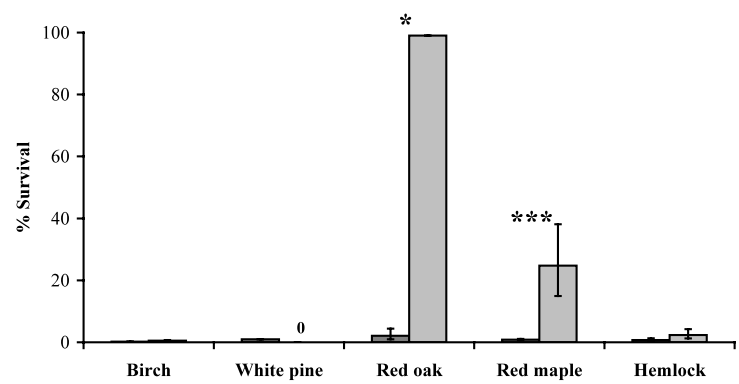

Fig. 5. Survival of first-year seedlings across the growing season (mean \pm 1 SEM) in hemlock ( $\square$ ) and red oak ( $\square$ ) stands. Means and standard errors were calculated from logit transformed data at the plot level $(n=1-66)$ and then backtransformed, and are shown for each year of study separately $(a-c)$. Missing values (no seedling emergence) are marked with a zero (" 0 "), while means that were significantly different between stand types are marked with asterisks $(* p<0.05$, $* * \mathrm{p}<0.01, * * * \mathrm{p}<0.001$, based on Bonferroni comparisons). some extent, between years of study (significant species $\times$ stand $\times$ year $\times$ month interaction, $F_{24,10518}=$ $6.45, \mathrm{p}<0.001)$. Birch and red maple both showed distinct regeneration dynamics in contrasting stand types that were relatively consistent across years of study (Fig. 6a, b). For birch, high seedling emergence in hemlock stands combined with low seedling survival created a spike in seedling abundance in hemlock stands in July $\left(0.2-2.0 \mathrm{~m}^{-2}\right)$, which soon disappeared (abundance down to $3-8 \times 10^{-4} \mathrm{~m}^{-2}$ by end of season), such that birch abundance did not differ between hemlock and red oak stands by the end of the growing season. In contrast, for red maple seedlings, there was no clear emergence peak, but significantly lower survival in hemlock stands led to lower overall seedling abundance in hemlock stands $\left(3-30 \times 10^{-4} \mathrm{~m}^{-2}\right)$ than in red oak stands $\left(1-15 \times 10^{-3} \mathrm{~m}^{-2}\right)$ later in the growing season.

Hemlock and white pine also exhibited contrasting seasonal changes in seedling abundance between hemlock and red oak stands, but these effects differed between years of study (Fig. 6c, d). In a similar way to birch, in 1997, high white pine and hemlock seedling emergence in hemlock stands led to greater seedling abundance in hemlock stands early in the season. For hemlock and white pine, however, survival in hemlock stands was greater than for birch, so they were able to maintain this higher seedling abundance in hemlock stands vs red oak stands throughout the growing season ( 40 vs $3 \times 10^{-4} \mathrm{~m}^{-2}$ for hemlock, 70 vs $3 \times 10^{-3}$ $\mathrm{m}^{-2}$ for white pine). In 1999, although hemlock seedling survival was lower in hemlock stands than in 1997, hemlock seedlings in the understorey underwent similar seasonal changes in abundance, still managing to maintain a higher seedling abundance in hemlock stands than in red oak stands by the end of the growing season. In poor seed years for both white pine (1998, 1999) and hemlock (1998), differences in seedling abundance between stand types were not significant. Red oak seedlings generally had low emergence and high survival, and did not show different regeneration patterns between hemlock and red oak stands during the first growing season (data not shown).

\section{Over-winter survival and later stages of seedling regeneration}

Species' responses to understorey conditions in both stand types continued to shape regeneration patterns of seedlings beyond their first growing season (Fig. 7). Canopy composition was a strong determinant of both seedling over-winter survival and seedling average age (significant species $\times$ stand interactions: for over-winter survival, $\mathrm{F}_{4,201}=5.68, \mathrm{p}<0.001$; for seedling age, $\left.\mathrm{F}_{4,380}=4.24, \mathrm{p}<0.01\right)$, and this effect was consistent across years (no significant species $\times$ stand $\times$ year inter- 


\section{a) Birch}

a) 1997

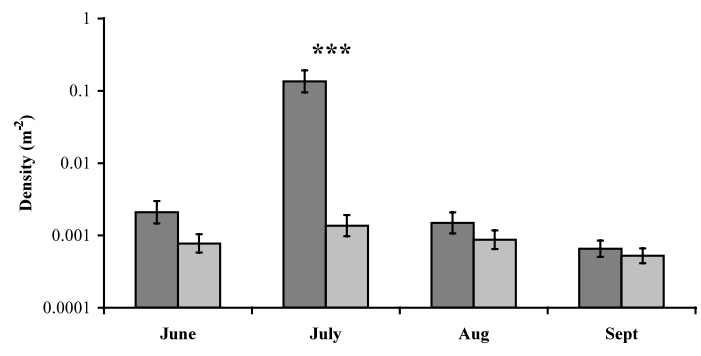

b) 1998

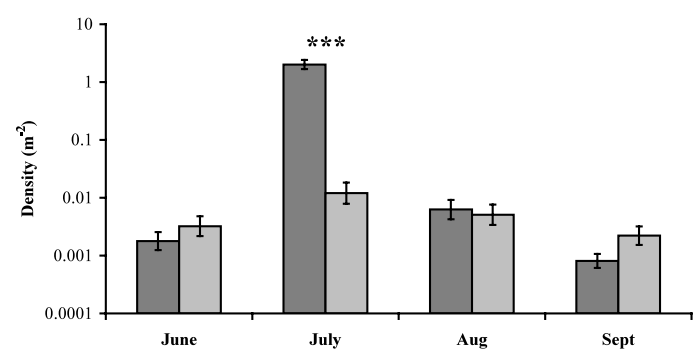

c) 1999

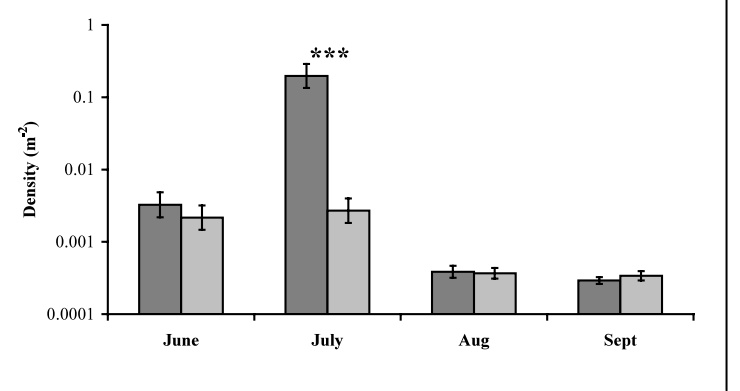

b) Red maple

a) 1997

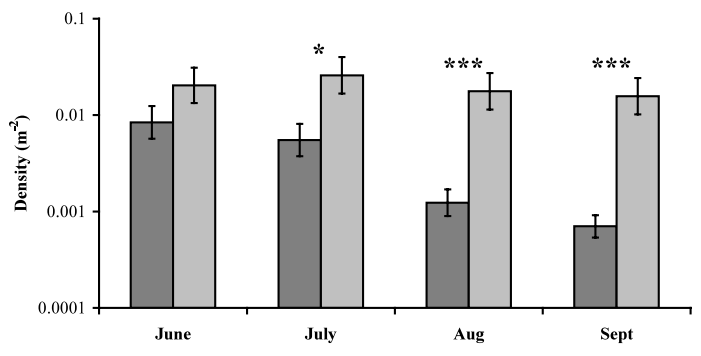

b) 1998

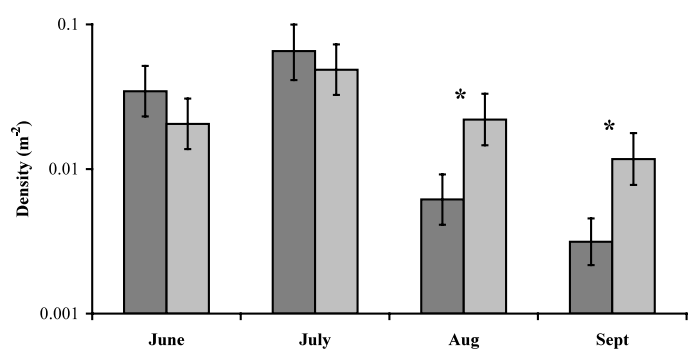

c) 1999

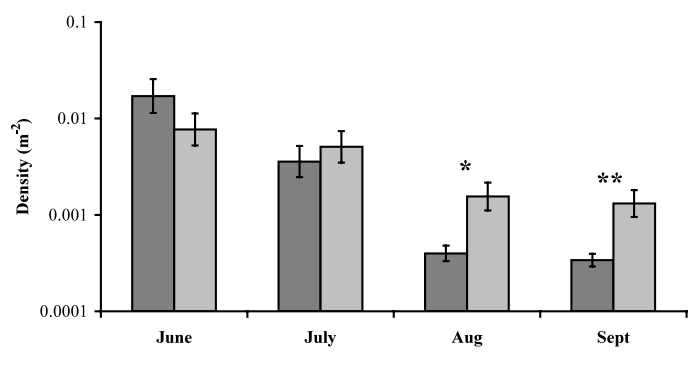

Fig. 6. Changes in first-year seedling abundance during the growing season (mean \pm 1 SEM) in hemlock $(\square)$ and red oak $(\square)$ stands. Means and standard errors were calculated from log transformed data at the plot level $(\mathrm{n}=90)$ and then back-transformed, and are shown for each species (a: birch, b: red maple, c: white pine, d: hemlock) and each year of study separately. Note $\log$ scale of $\mathrm{y}$-axis. Means that were significantly different between stand types are marked with asterisks $(* \mathrm{p}<0.05, * * \mathrm{p}<0.01$, $* * * \mathrm{p}<0.001$, based on Bonferroni comparisons). Red oak is not included, given its consistently low seedling abundance, and the lack of significant differences between years and stand types. Figure $6 \mathrm{c}$ and $\mathrm{d}$ on next page.

action, $\mathrm{F}_{1,201}=0.90$ for over-winter survival, $\mathrm{F}_{7,380}=$ 1.33 for age, $\mathrm{p}>0.05$ for both). All species but hemlock had significantly higher over-winter survival and higher average seedling age in red oak stands than in hemlock stands (Fig. 7a, b). Hemlock had very few seedlings surviving over the winter in any stand, and thus we found very few hemlock seedlings that were older than one year. Older seedlings $(>5$ yrs old, 


\section{c) White pine}

a) 1997

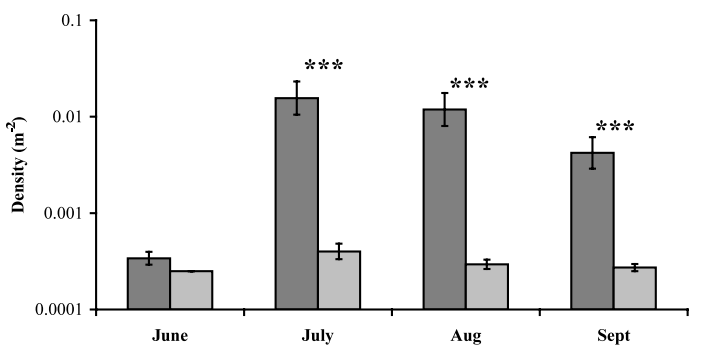

b) 1998

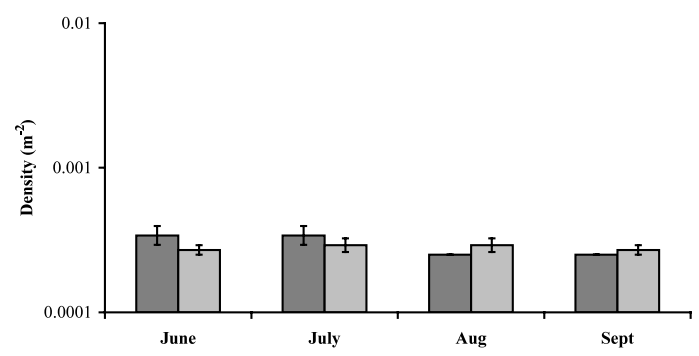

c) 1999

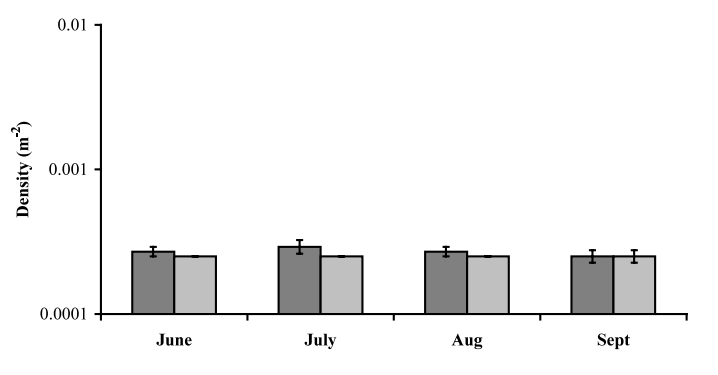

\section{d) Hemlock}

a) 1997

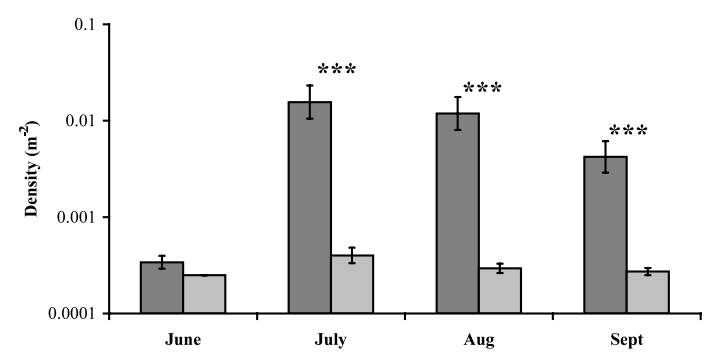

b) 1998

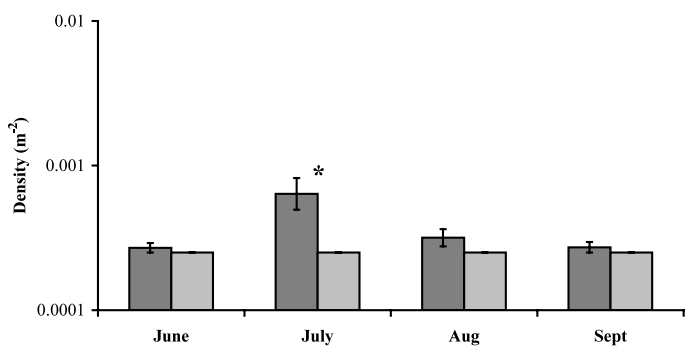

c) 1999

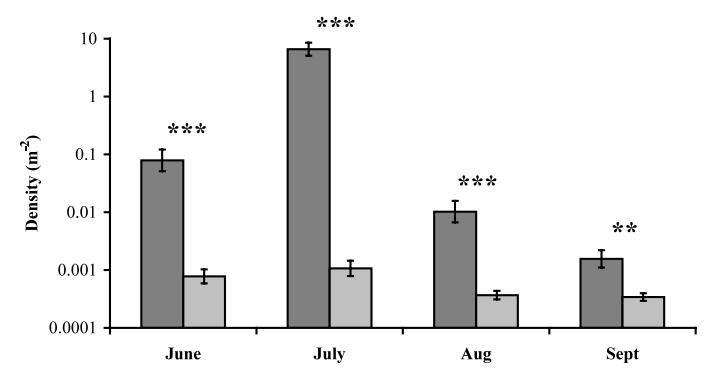

Fig. 6.

$<50 \mathrm{~cm}$ height) also showed differential responses to stand type. Red oak, red maple and birch all had significantly greater seedling abundance in red oak stands than in hemlock stands (Fig. 7c, $\chi_{1}^{2}=7.6-22.3$, $\mathrm{p}<0.01)$, while hemlock had greater abundance in hemlock stands than in red oak stands $\left(\chi_{1}^{2}=8.1, \mathrm{p}<\right.$ $0.01)$. White pine had few older seedlings in either stand type.
Seedling dynamics at these later stages were examined further using age structure analysis (Fig. 8). The rapid decline in seedling abundance after the first year in hemlock stands highlights the low survival rates in these stands compared with red oak stands. If we assume constant annual seed rain (for illustrative purposes at least), the slopes of these annual survivorship curves expressed on a log scale provide an integrated 
a) Over-winter Survival

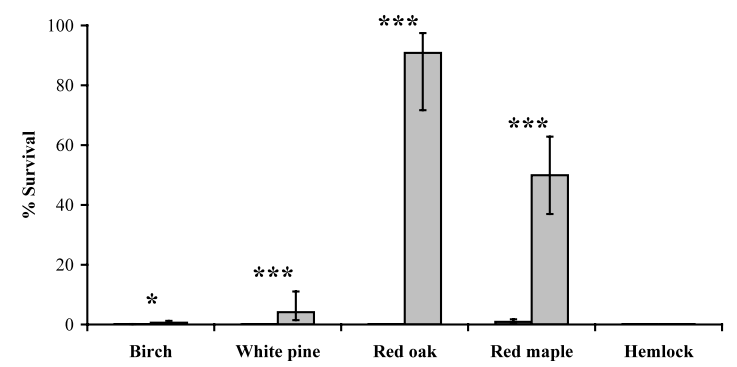

b) Seedling Age

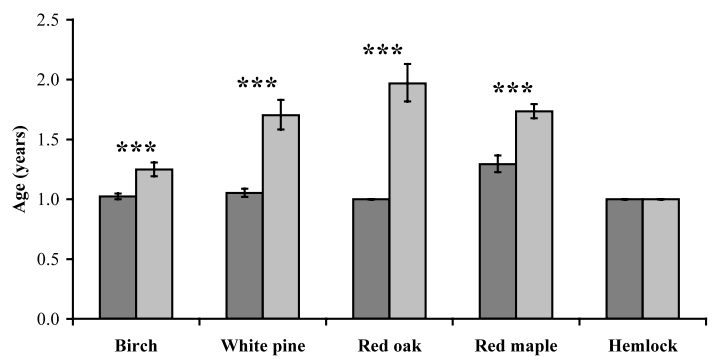

c) Older Seedling Abundance

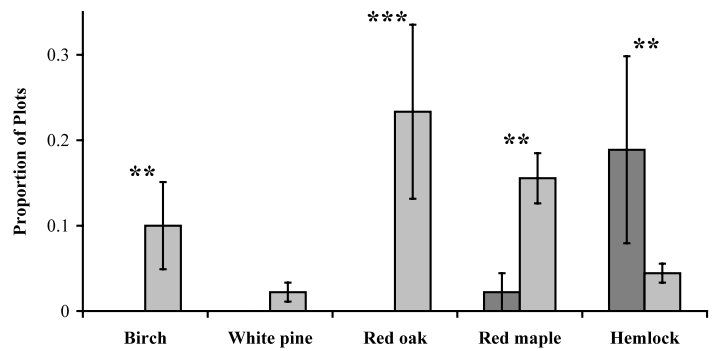

Fig. 7. Regeneration dynamics (mean \pm 1 SEM) for seedlings surviving their first growing season in hemlock $(\square)$ and red oak ( $\square$ ) stands: (a) Survival during the first winter, (b) Average age of seedlings (only $1-5$ yrs old) at the end of each growing season, (c) Proportion of plots containing seedlings greater than 5 yrs old and less than $50 \mathrm{~cm}$ height. Means and standard errors were calculated from transformed data at the plot level for over-winter survival (logit, $\mathrm{n}=1-91$ ) and seedling age (log, $\mathrm{n}=5-165)$, and then back-transformed, and for older seedlings at the site level $(n=3)$. Results are shown pooled across both winters of study for (a), and across all study years for (b). Means that were significantly different between stand types are marked with asterisks: $* p<0.05$, $* * \mathrm{p}<0.01, * * * \mathrm{p}<0.001$, based on Bonferroni comparisons for (a) and (b), and Mantel-Haenszel test for (c).

measure of seedling mortality (from slopes) and allow calculation of expected seedling life-span (inverse of mortality) for species whose abundance did not drop to zero (Gotelli 1998). In line with seedling age results, all species except hemlock had lower seedling mortality and greater seedling life-spans in red oak stands than in hemlock stands $(33 \%$ vs $75 \%$ and 3.6 vs $1.6 \mathrm{yrs}$; Table 2). High over-winter mortality for first-year hemlock seedlings in both stands meant that we did not record any seedlings older than one year in either stand.

All seedlings up to five years old were harvested at the end of the 1999 growing season. Species showed contrasting growth responses to differences in understorey conditions between hemlock and red oak stands (significant species $\times$ stand interaction $F_{4,166}=2.67$, $\mathrm{p}<0.05$ ), and this effect persisted when the effects of seedling age were removed (significant age $\times$ species interaction, $\mathrm{F}_{3,166}=6.49, \mathrm{p}<0.001$; but no significant age $\times$ species $\times$ stand interaction, $F_{1,166}=1.05, \quad p>$ 0.05). Both red maple and hemlock seedlings were significantly larger in general in red oak stands than in hemlock stands (2- and 5-fold increases in biomass, respectively) (Fig. 9). Other species showed a tendency for increased biomass in red oak vs hemlock stands, but these changes were not significant.

\section{Stand environmental characteristics}

Hemlock and red oak stands differed significantly in light availability at the forest floor and at $1 \mathrm{~m}$ above the floor $\left(\mathrm{F}_{1,4}=10.42-57.48, \mathrm{p}<0.05\right)$, with hemlock stands commonly experiencing light levels that were one-third to one-half that of their red oak counterparts (Table 3). Understorey herbs and shrubs had a larger effect on light availability in red oak stands than in hemlock stands, as light at the forest floor was on average $25 \%$ lower than at $1 \mathrm{~m}$ in red oak stands, while there was little difference in hemlock stands. In contrast to stand effects on light availability, many soil characteristics showed greater variability among sites than between stand types. Water availability barely differed between stand types $\left(\mathrm{F}_{1,4}=0.01\right.$ and 1.73, $\left.\mathrm{p}>0.05\right)$. Hemlock stands showed a trend for lower nitrogen availability (as assessed by both in situ buried bag mineralization rates and by resin bag ammonium and nitrate), but no differences were significant $\left(\mathrm{F}_{1,4}=\right.$ $0.01-0.66, \mathrm{p}>0.05)$. $\mathrm{pH}$ was one soil characteristic that did differ significantly between stand types $\left(\mathrm{F}_{1,4}=8.18\right.$, $\mathrm{p}<0.05)$, with soils in hemlock stands having a lower $\mathrm{pH}$ than those in red oak stands (by $0.4 \mathrm{pH}$ units on average). Hemlock stands also had deeper organic soil horizons than did red oak stands $\left(\mathrm{F}_{1,4}=8.27, \mathrm{p}<0.05\right)$, but litter depth itself did not differ between stand types $\left(F_{1,4}=2.22, p>0.05\right)$. Hemlock and red oak stands had similar annual quantities of litter fall (close to 300 $\mathrm{g} \mathrm{m}^{-2}$ ), although litter composition showed clear differences between stand types $\left(\mathrm{F}_{1,4}=13.38\right.$ for $\%$ broadleaved litter and 82.59 for $\%$ coniferous litter, $\mathrm{p}<0.05$ and 0.001 , respectively). More than one-third of the litter fall in hemlock stands was composed of coniferous litter, while broad-leaved litter dominated litter fall in red oak stands (Table 3 ). 
Fig. 8. Seedling $\log _{10}$ abundance by age class, summed across plots and sites and averaged across years, showing age structure for each individual species in both hemlock (a) and red oak (b) stands.

\section{a) Hemlock stands}

-O-Birch $\triangle$ Red maple $-\square$-Red oak

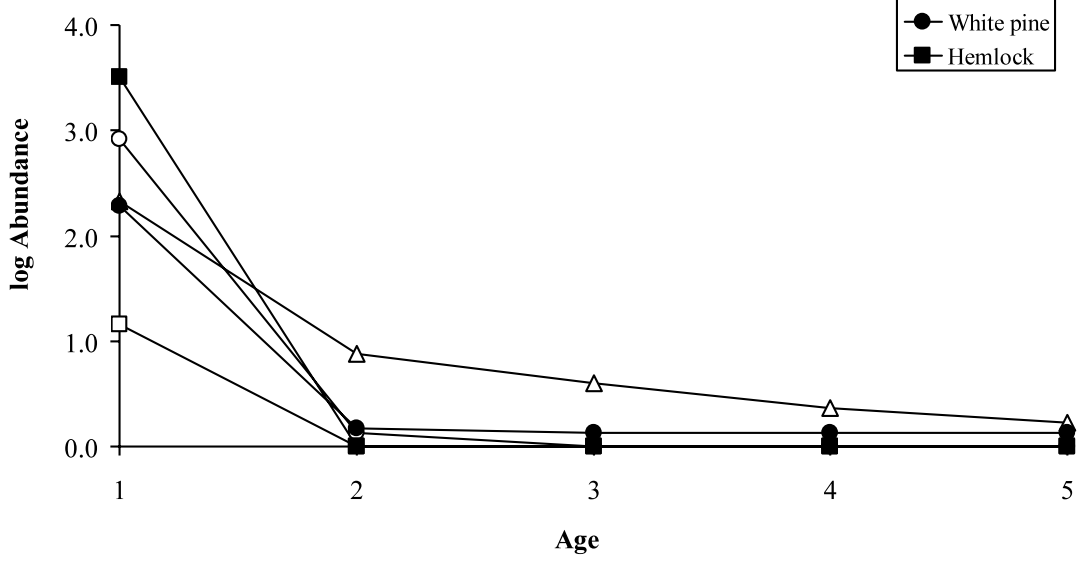

b) Red oak stands

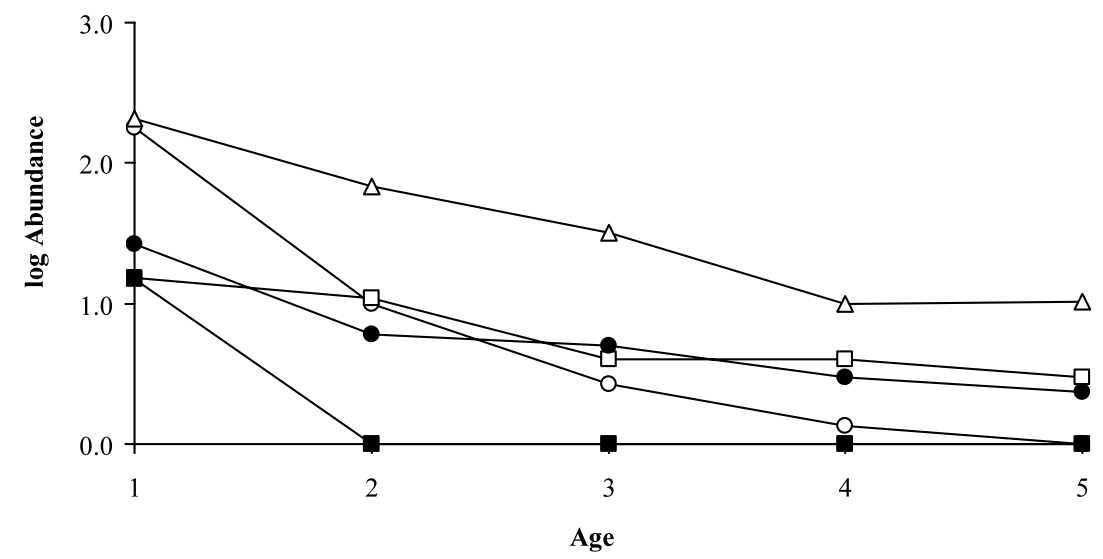

Relationships between seedling regeneration and environmental variables

Overall, variation in both $\mathrm{pH}$ and light correlated best with seedling regeneration patterns in the understorey of hemlock and red oak stands (Table 4). Water availability correlated positively with proportional seedling emergence from seed (Table 4a), but rarely correlated with seedling patterns at later stages. Light availability was negatively related to proportional seedling emergence for all species, but only explained a substantial proportion $(\sim 20 \%)$ of the variation in seedling emergence for the smaller seeded species.

Table 2. Mortality rates and expected seedling life-spans in the understorey of each stand type, calculated from age structure analysis.

\begin{tabular}{|c|c|c|c|c|}
\hline \multirow[b]{2}{*}{ Species } & \multicolumn{2}{|c|}{ Hemlock stands } & \multicolumn{2}{|c|}{ Red oak stands } \\
\hline & Mortality $^{\mathrm{a}}$ & Life-span ${ }^{\mathrm{b}}$ & Mortality $^{\mathrm{a}}$ & Life-span ${ }^{\mathrm{b}}$ \\
\hline Birch & 1.00 & 1.00 & 0.54 & 1.86 \\
\hline Red maple & 0.47 & 2.11 & 0.34 & 2.92 \\
\hline Red oak & 1.00 & 1.00 & 0.19 & 5.39 \\
\hline White pine & 0.44 & 2.29 & 0.24 & 4.16 \\
\hline Hemlock & 1.00 & 1.00 & 1.00 & 1.00 \\
\hline
\end{tabular}

${ }^{a}$ Mortality rates (proportion dying each year) calculated from age-abundance slopes in Fig. 9. When seedling abundance dropped to zero after the first year, mortality was set at 1 (by definition)

${ }^{\mathrm{b}}$ Expected seedling life-span (1/mortality), expressed in years. 


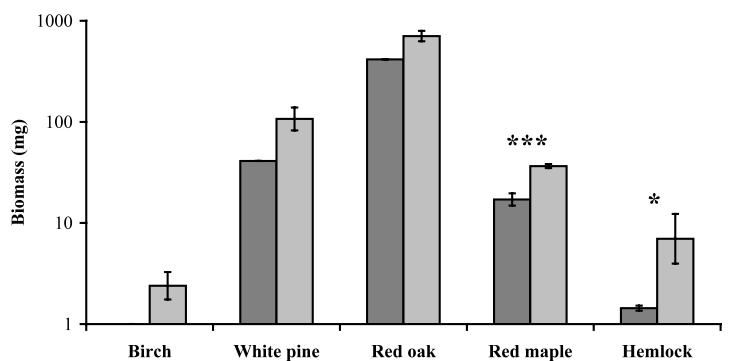

Fig. 9. Seedling biomass (mean \pm 1 SEM) in hemlock $(\square)$ and red oak $(\square)$ stands. Means and standard errors were calculated from log transformed data for each seedling $(n=1-150)$ and then back-transformed, and are shown pooled across all seedlings ages ( $1-5 \mathrm{yrs})$. Note log scale of y-axis. Means that were significantly different between stand types are marked with asterisks $(* \mathrm{p}<0.05, * * \mathrm{p}<0.01, * * * \mathrm{p}<0.001$, based on Bonferroni comparisons).

Early seedling survival and growth were both related almost exclusively to light availability and soil $\mathrm{pH}$ (Table 4b). The broad-leaved species, birch and red maple, showed a clear increase in survival during the growing season with both increasing light availability and increasing $\mathrm{pH}$ (less acid). Based on regression slopes, a $1.5 \%$ increase in light and 0.4 units increase in $\mathrm{pH}$ (difference between red oak and hemlock stands) led to survival increases of $7-22 \%$ for birch and $9-20 \%$ for maple, depending on the year of study. White pine survival similarly showed a positive but weaker relationship with light ( $5 \%$ shift), but only in the study year with high white pine seedling abundance (1997). Hemlock survival was not related to $\mathrm{pH}$ and was only mildly related to light availability $\left(r^{2}<2 \%\right)$, and this effect was only significant in one of the study years (1999). Overwinter survival of all species except hemlock was also positively related to $\mathrm{pH}$, with particularly strong effects for red oak and white pine (Table $4 \mathrm{c}$ ). Again, a 1.5\% increase in light and a 0.4 unit increase in $\mathrm{pH}$ led to a $8-26 \%$ increase in over-winter survival, depending on species. In contrast, light (rather than $\mathrm{pH}$ ) was the only environmental factor measured that related to early seedling growth, with the conifers (white pine and hemlock) and red maple showing increased growth $(10-25 \mathrm{mg})$ with increased light availability (Table 4d).

These effects of light and $\mathrm{pH}$ on early seedling performance carried through to later stages of regeneration. Ages of white pine, red oak, and red maple seedlings in the understorey were all positively related to both light availability and $\mathrm{pH}$ (not red maple), so that microsites with higher light availability and less acid soils had higher seedling age on average (Table 4e), e.g. $1.5 \%$ increase in light and 0.4 units increase in $\mathrm{pH}$ led to a 0.75 increase in red oak seedling age. Age was also negatively related to water availability for most species. Older seedling age classes showed similar environmental relationships to those less than five years old (Table 4f). Red maple seedling abundance was positively related to both light and $\mathrm{pH}$, while abundance of white pine was related predominantly to light and that of red oak to $\mathrm{pH}$. In contrast, there was a significant negative coefficient for the regression between hemlock older seedling abundance and light availability, such that plots with higher light availability were less likely to contain hemlock seedlings.

\section{Discussion}

\section{General nature of canopy-seedling feedbacks}

Results of the present experiment have clearly demonstrated that, in mixed conifer broad-leaved forests, feedbacks between canopy composition and seedling

Table 3. Summary of environmental measurements in hemlock and red oak stands, showing means for each stand type and significance of difference.

\begin{tabular}{|c|c|c|c|c|c|c|}
\hline Factor & Position/Type & Year & Units & Hemlock $^{\mathrm{a}}$ & Red oak ${ }^{a}$ & $\mathrm{P}^{\mathrm{b}}$ \\
\hline \multirow[t]{4}{*}{ Light } & \multirow[t]{2}{*}{$1 \mathrm{~m}$} & 1997 & mol day $^{-1}$ & 0.40 & 1.22 & $* *$ \\
\hline & & 1999 & $\%$ PFD & 1.65 & 3.98 & $*$ \\
\hline & \multirow[t]{2}{*}{$5 \mathrm{~cm}$} & 1997 & mol day ${ }^{-1}$ & 0.37 & 0.91 & $* *$ \\
\hline & & 1999 & $\%$ PFD & 1.54 & 2.98 & $* *$ \\
\hline \multirow[t]{3}{*}{ Nitrogen } & Mineralization & 1997 & $\mathrm{mg} \mathrm{kg}^{-1}$ & 65.6 & 68.6 & NS \\
\hline & Resin $\mathrm{NH}_{4}^{+}$ & 1999 & $\mathrm{mg} \mathrm{kg}^{-1}$ & 4.63 & 4.80 & NS \\
\hline & Resin $\mathrm{NO}_{3}^{-}$ & 1999 & $\mathrm{mg} \mathrm{kg}^{-1}$ & 0.13 & 0.84 & NS \\
\hline \multirow[t]{4}{*}{ Water } & \multirow[t]{2}{*}{ O horizon } & 1997 & $\mathrm{~cm}^{3} \mathrm{~cm}^{-3}$ & 0.12 & 0.08 & NS \\
\hline & & 1999 & $\mathrm{~cm}^{3} \mathrm{~cm}^{-3}$ & 0.07 & 0.05 & NS \\
\hline & \multirow[t]{2}{*}{ A horizon } & 1997 & $\mathrm{~cm}^{3} \mathrm{~cm}^{-3}$ & 0.31 & 0.31 & NS \\
\hline & & 1999 & $\mathrm{~cm}^{3} \mathrm{~cm}^{-3}$ & 0.27 & 0.26 & NS \\
\hline $\mathrm{pH}$ & - & 1998 & - & 3.92 & 4.39 & $*$ \\
\hline \multirow[t]{2}{*}{ Soil profile } & Litter depth & 1998 & $\mathrm{~cm}$ & 1.34 & 1.52 & NS \\
\hline & O horizon depth & 1998 & $\mathrm{~cm}$ & 3.54 & 2.93 & $*$ \\
\hline \multirow[t]{2}{*}{ Litter fall } & Conifer & 1998 & $\mathrm{~g} \mathrm{~m}^{-2}$ & 114.0 & 15.8 & $* * *$ \\
\hline & Broad-leaved & 1998 & $\mathrm{~g} \mathrm{~m}^{-2}$ & 179.9 & 280.9 & $* * *$ \\
\hline
\end{tabular}

${ }^{\text {a }}$ Means of three sites per stand type, with 30 plots nested within each site.

${ }^{\mathrm{b}}$ Significance of stand effect (tested over site mean square) in multivariate analyses of variance: Ns $\mathrm{p}>0.05$, $* \mathrm{p}<0.05$, $* *$ $\mathrm{p}<0.01, * * * \mathrm{p}<0.001$. 
Table 4. Results of multiple regression models examining dependence of seedling regeneration variables on environmental factors. For each variable, $\mathrm{r}^{2}$ values, regression coefficients, and their significance, are shown for individual species/year/month combinations (on a plot-level basis), depending on the degree of interaction in the main model.

\begin{tabular}{|c|c|c|c|c|c|c|c|}
\hline Factor $^{\mathrm{b}}$ & Species & Year & $r^{2}$ & Slope ${ }^{c}$ & $\mathrm{n}$ & $\mathrm{F}$ & $\mathrm{P}^{\mathrm{d}}$ \\
\hline \multicolumn{8}{|c|}{ a) Emergence ${ }^{a}$} \\
\hline \multirow[t]{8}{*}{ Light } & Birch & 1998 & 18.14 & -0.366 & 180 & 39.22 & $* * *$ \\
\hline & & 1999 & 7.24 & -0.215 & 180 & 13.82 & $* * *$ \\
\hline & Red oak & 1998 & 2.92 & -0.124 & 141 & 4.16 & $* *$ \\
\hline & & 1999 & 3.84 & -0.148 & 97 & 3.75 & \\
\hline & Red maple & 1998 & 3.70 & -0.167 & 173 & 6.54 & $* *$ \\
\hline & & 1999 & 2.33 & -0.172 & 161 & 3.77 & \\
\hline & Hemlock & 1998 & 0.77 & -0.053 & 92 & 0.69 & NS \\
\hline & & 1999 & 19.35 & -0.449 & 179 & 42.22 & $* * *$ \\
\hline \multirow[t]{8}{*}{ Water } & Birch & 1998 & 1.63 & 0.113 & 180 & 2.93 & * \\
\hline & & 1999 & 10.30 & 0.265 & 180 & 20.33 & $* * *$ \\
\hline & Red oak & 1998 & 9.54 & 0.239 & 141 & 14.56 & $* * *$ \\
\hline & & 1999 & 1.55 & 0.078 & 97 & 1.48 & NS \\
\hline & Red maple & 1998 & 11.95 & 0.310 & 173 & 23.07 & $* * *$ \\
\hline & & 1999 & 1.84 & 0.143 & 161 & 2.96 & * \\
\hline & Hemlock & 1998 & 0.82 & 0.053 & 92 & 0.74 & NS \\
\hline & & 1999 & 13.36 & 0.382 & 179 & 27.15 & $* * *$ \\
\hline \multicolumn{8}{|c|}{ b) Survival (growing season) a $^{a}$} \\
\hline \multirow[t]{12}{*}{ Light } & Birch & 1997 & 6.82 & 0.342 & 167 & 12.00 & $* * *$ \\
\hline & & 1998 & 16.03 & 0.460 & 259 & 48.88 & $* * *$ \\
\hline & & 1999 & 2.33 & 0.154 & 161 & 3.78 & * \\
\hline & White pine & 1997 & 3.87 & 0.105 & 254 & 10.12 & $* *$ \\
\hline & & 1998 & 20.54 & 0.426 & 13 & 2.64 & NS \\
\hline & & 1999 & 0.00 & 0.000 & 4 & 0.00 & NS \\
\hline & Red maple & 1997 & 11.74 & 0.344 & 249 & 32.72 & $* * *$ \\
\hline & & 1998 & 4.86 & 0.196 & 324 & 16.40 & $* * *$ \\
\hline & & 1999 & 16.20 & 0.406 & 191 & 36.34 & $* * *$ \\
\hline & Hemlock & 1997 & 0.22 & 0.048 & 109 & 0.23 & NS \\
\hline & & 1998 & 8.04 & 0.501 & 16 & 1.15 & NS \\
\hline & & 1999 & 1.64 & 0.139 & 226 & 3.71 & $*$ \\
\hline \multirow[t]{12}{*}{$\mathrm{pH}$} & Birch & 1997 & 1.23 & 0.102 & 167 & 2.05 & NS \\
\hline & & 1998 & 7.69 & 0.226 & 259 & 21.31 & $* * *$ \\
\hline & & 1999 & 3.27 & 0.135 & 161 & 5.35 & * \\
\hline & White pine & 1997 & 0.16 & 0.041 & 254 & 0.40 & NS \\
\hline & & 1998 & 22.87 & 0.720 & 13 & 3.03 & NS \\
\hline & & 1999 & 0.00 & 0.000 & 4 & 0.00 & NS \\
\hline & Red maple & 1997 & 13.37 & 0.371 & 249 & 37.95 & $* * *$ \\
\hline & & 1998 & 5.39 & 0.243 & 324 & 18.27 & $* * *$ \\
\hline & & 1999 & 9.61 & 0.294 & 191 & 19.99 & $* * *$ \\
\hline & Hemlock & 1997 & 1.65 & -0.143 & 109 & 1.78 & NS \\
\hline & & 1998 & 10.82 & 0.834 & 16 & 1.60 & NS \\
\hline & & 1999 & 0.97 & 0.089 & 226 & 2.19 & NS \\
\hline \multicolumn{8}{|c|}{ c) Survival (over winter) ${ }^{a}$} \\
\hline & Birch & & 7.16 & 0.132 & 62 & 4.55 & * \\
\hline & White pine & & 32.40 & 0.558 & 95 & 44.13 & $* * *$ \\
\hline & Red oak & & 22.46 & 0.726 & 36 & 9.58 & $* *$ \\
\hline & Red maple & & 4.03 & 0.229 & 135 & 5.54 & * \\
\hline & Hemlock & & 1.36 & 0.023 & 37 & 0.47 & NS \\
\hline \multicolumn{8}{|c|}{ d) Growth ${ }^{\mathrm{a}}$} \\
\hline \multirow[t]{5}{*}{ Light } & Birch & & 2.33 & 0.061 & 7 & 0.104 & NS \\
\hline & White pine & & 46.18 & 0.267 & 11 & 7.079 & * \\
\hline & Red oak & & 7.93 & 0.077 & 29 & 2.248 & NS \\
\hline & Red maple & & 4.20 & 0.073 & 164 & 7.054 & $* *$ \\
\hline & Hemlock & & 24.95 & 0.206 & 54 & 16.974 & $* * *$ \\
\hline \multicolumn{8}{|c|}{ e) Seedling age ${ }^{a}$} \\
\hline Light & Birch & & 2.33 & 0.119 & 81 & 1.87 & NS \\
\hline & White pine & & 10.19 & 0.264 & 123 & 13.62 & $* * *$ \\
\hline & Red oak & & 36.29 & 0.821 & 71 & 38.75 & $* * *$ \\
\hline & Red maple & & 6.38 & 0.249 & 227 & 15.28 & $* * *$ \\
\hline Water & Birch & & 0.16 & 0.023 & 81 & 0.13 & NS \\
\hline & White pine & & 14.50 & -0.463 & 123 & 20.36 & $* * *$ \\
\hline & Red oak & & 23.30 & -0.571 & 71 & 20.67 & $* * *$ \\
\hline & Red maple & & 2.12 & -0.132 & 227 & 4.85 & * \\
\hline $\mathrm{pH}$ & Birch & & 2.30 & 0.069 & 81 & 1.84 & NS \\
\hline & White pine & & 13.26 & 0.416 & 123 & 18.35 & $* * *$ \\
\hline & Red oak & & 13.97 & 0.554 & 71 & 11.05 & $* *$ \\
\hline & Red maple & & 0.44 & 0.069 & 227 & 1.00 & NS \\
\hline
\end{tabular}


Table 4. (Continued).

\begin{tabular}{|c|c|c|c|c|c|c|c|}
\hline Factor $^{\mathrm{b}}$ & Species & Year & $r^{2}$ & Slope ${ }^{c}$ & $\mathrm{n}$ & $\mathrm{F}$ & $\mathrm{P}^{\mathrm{d}}$ \\
\hline \multicolumn{8}{|c|}{ f) Older seedling presence/absence ${ }^{a}$} \\
\hline \multirow[t]{5}{*}{ Light } & Birch & & - & -0.010 & 180 & 0.03 & NS \\
\hline & White pine & & - & 0.216 & 180 & 14.85 & $* * *$ \\
\hline & Red oak & & - & 0.065 & 180 & 2.27 & NS \\
\hline & Red maple & & - & 0.105 & 180 & 5.95 & * \\
\hline & Hemlock & & - & -0.119 & 180 & 4.56 & * \\
\hline \multirow[t]{5}{*}{$\mathrm{pH}$} & Birch & & - & 0.194 & 180 & 7.62 & $* *$ \\
\hline & White pine & & - & 0.083 & 180 & 0.45 & NS \\
\hline & Red oak & & - & 0.178 & 180 & 7.42 & $* *$ \\
\hline & Red maple & & - & 0.133 & 180 & 3.92 & * \\
\hline & Hemlock & & - & -0.073 & 180 & 1.08 & NS \\
\hline
\end{tabular}

${ }^{a} \mathrm{Y}$ variables were transformed to meet assumptions of linear regression models: log for emergence, growth, and age, and logit for survival. Older seedling presence/absence was investigated with a purely logistic regression model, and thus $\mathrm{r}^{2}$ values are not shown in this case.

${ }^{\mathrm{b}}$ Only factors that produced significant terms in the multiple regression are shown.

${ }^{\mathrm{c}}$ Regression slopes are shown as standardized partial regression coefficients (scaled to standard deviations of variables, thus between -1 to +1$)$. Significant slopes $(p<0.05)$ shown in bold

${ }^{\mathrm{d}} \mathrm{NS} \mathrm{p}>0.05, * \mathrm{p}<0.05, * * \mathrm{p}<0.01, * * * \mathrm{p}<0.001$.

dynamics may act at many stages of regeneration, and thus that current stand structure can influence future forest community dynamics. In particular, we found evidence for a positive feedback operating in hemlock stands. Under a hemlock canopy, hemlock seedlings were favoured over other species' seedlings. We found a persistent bank of older hemlock seedlings in the understorey of hemlock stands that did not occur in red oak stands (Fig. 7c). This positive feedback in hemlock stands has been demonstrated in a previous study (Catovsky and Bazzaz 2000), and may allow hemlock to dominate particular stands for many generations (Frelich et al. 1993). Hemlock is a quintessential late successional species, which has been shown to be able to persist in the low light conditions of its own canopy for many generations (Godman and Lancaster 1990, Kobe et al. 1995), and may fit into Clements' (1916) definition of a classic 'climax' species. White pine was the only other species that showed some evidence of being favoured under hemlock stands, but these effects were only apparent during the first growing season and disappeared soon after.

In red oak stands, there was also evidence for strong feedbacks between canopy composition and patterns of seedling regeneration. In this case, however, the understorey conditions in red oak stands favoured persistence of several broad-leaved tree species, not just red oak (the canopy dominant). A true positive feedback would only arise if red oak was clearly favoured at the expense of all other species under its own canopy (Wilson and Agnew 1992). In the present experiment, red maple and red oak, and even birch to some degree, were all favoured over hemlock in red oak stands compared with hemlock stands (Fig. 7c). Stand-level canopyseedling interactions have been documented in other mixed temperate forests (Bartlett et al. 1991, Cornett et al. 1997), although these feedbacks are not always positive, leading to reciprocal replacement effects on the landscape level in some cases (Woods 1979, Hiura and Fujiwara 1999).

Canopy-seedling feedbacks will not act in isolation in forests, but rather will interact with other communitylevel processes operating in temperate forests, e.g. successional dynamics (Poulson and Platt 1996, Woods 2000a), and forest responses to canopy disturbance (Frelich and Reich 1999). Tree replacements in forests typically take place following canopy disturbance-even for hemlock, the most shade tolerant species in our study region (Kelty 1986). The understorey seedling bank sets the starting composition of any seedling community exposed to a future canopy opening, and so these early dynamics put an important constraint on seedling responses to disturbance. However, we should be careful about extending our results much beyond these early life stages, as seedling responses to low light availability (closed canopy) may not necessarily reflect responses to canopy gap formation (Latham 1992). Nevertheless, we can draw some valid conclusions about the seedling establishment phase. For example, our results strongly indicate that the presence of red oak in mixed temperate forests could act to slow the course of succession by preventing early establishment of hemlock in the understorey of such stands (e.g. Davis et al. 1998).

\section{Demographic processes underlying canopy-seedling feedbacks}

Seed rain, emergence from the soil seed bank, and seedling survival in the understorey were all significant components of the canopy-seedling feedbacks acting in both stand types, and species differed in the way that each component contributed to their relative regeneration success. For hemlock, relatively high seed input and high proportional seedling emergence in hemlock 
stands compared with red oak stands led to early dominance of the understorey seedling bank in these stands. The particularly low dispersal distances of hemlock (Ribbens et al. 1994) likely enhanced the high degree of spatial structure in seed rain brought about by the heterogeneous distribution of canopy trees (see also Cornett et al. 1997). High inputs of hemlock seeds were reinforced by higher proportional seedling emergence in hemlock stands compared to red oak stands. The higher amount of conifer litter in hemlock stands may lead to a greater proportion of mineral soil being exposed, providing an ideal substrate for emergence of small seeded species such as hemlock (Collins 1990, Yoshida and Ohsawa 1999).

Most species showed substantially lower survival (first and subsequent growing seasons) in hemlock stands compared with red oak stands, and thus rarely made a significant contribution to the understorey seedling bank in hemlock stands. In contrast, hemlock commonly showed no difference in response between stand types. Hemlock's extreme shade tolerance (Kobe et al. 1995) allowed it to persist and maintain this early dominance under its own canopy despite very low light availability (Fig. 6d). Even birch, which showed remarkably high seed rain and high seedling emergence in hemlock stands, only occurred as temporary pulse of seedlings, due to high mortality under the low light conditions characteristic of hemlock stands (Catovsky and Bazzaz 2000, Yorks et al. 2000).

Canopy-seedling feedbacks in red oak stands also operated at many stages of regeneration - from survival both during the growing season and over-winter, to age structure of the understorey seedling bank, and persistence of older understorey seedlings. Red oak stands favoured a suite of mid-successional broadleaved species over hemlock and, to some extent, white pine. The conifers were both partially excluded from red oak stands by virtue of their low seed input and low seedling emergence in such stands. Hemlock rarely made any significant contribution to the red oak seedling bank. Red maple was able to dominate many understorey seedling plots in red oak stands by virtue of adequate seed rain, high seedling survival over many growing seasons (as evidenced from its more even age structure) and good seedling growth. Red oak was also favoured in red oak stands (especially over-winter survival), but the relatively low seed inputs during all three years of study prevented oak from developing an adequate seedling bank. Birch suffered higher mortality than either red maple or red oak, but still maintained a small seedling bank in red oak stands. These early dynamics were consistent with the finding that these broad-leaved species retain a bank of persistent older seedlings in red oak stands and very few in hemlock stands.

Some stand and species effects were more contingent on year of study. Seed inputs set the upper limit for a species' contribution to the seedling bank in a particular year, and thus annual patterns of seed production affected the strength of canopy-seedling feedbacks from year to year. These effects were particularly noticeable for the conifers, which tend to undergo greater variation in seed set than the broad-leaved species (Houle 1994, Koenig and Knops 1998). For example, in the one study year with poorer hemlock seed production and seedling emergence (1998), hemlock made a small contribution to the early stages of the seedling bank in hemlock stands, providing little evidence for a positive feedback in these stands. For the most part, however, we found remarkable consistency in seedling survival over the three study years, and these effects acted to unify seedling dynamics over the three growing seasons. Red oak was the only species that showed substantial annual variation in survival differences between stand types, with significant stand-level differences only appearing in the last year. 1999 was the driest summer during the study by far $(22.3 \mathrm{~cm}$ rainfall, vs 42.4 and $38.5 \mathrm{~cm}$ for 1997 and 1998, respectively). Perhaps the large size of red oak seeds and seedlings makes them relatively resistant to mortality at early growth stages, except under more severe conditions. However, red oak had consistently lower over-winter survival in hemlock stands than in red oak stands, and this component of seedling demography likely drove the positive feedbacks in oak stands. The magnitude of canopy-seedling effects will change from year-to-year, as a result of variation in seed production and climate factors, but the essence of these canopy-seedling feedbacks will remain due to the consistency of most demographic processes, e.g. proportional emergence, seedling first-year, and over-winter survival.

\section{Mechanisms underlying canopy-seedling feedbacks}

Early seedling dynamics will be a product of species' life-history traits and their local resource environment. Seed size imposes an initial constraint on seedling behaviour (Hewitt 1998, Walters and Reich 2000), with large-seeded species typically showing higher seedling survival and size at early growth stages, e.g. red oak, red maple, and white pine (Fig. 5 and 8). Nevertheless, canopy-seedling feedback effects may operate within this constraint. In the present study, light availability and soil $\mathrm{pH}$ differed substantially between stand types, and species-specific responses to canopy-mediated variation in both these factors explained much of the variation in seedling dynamics between the two stand types. For most species in the understorey seedling bank (birch, red maple, red oak, white pine), many components of seedling regeneration were positively associated with relatively small changes in light availability and/or $\mathrm{pH}$, which was consistent with the finding that performance of these species was favoured 
in red oak stands (higher light and $\mathrm{pH}$ ) over hemlock stands. In contrast, regeneration of hemlock seedlings was never significantly related to soil $\mathrm{pH}$ and only rarely related to light availability. Hemlock seedling growth was positively related to light availability, while seedling emergence and presence of older hemlock seedlings in the understorey showed a significant negative association with light, again consistent with the result that hemlock regeneration was favoured in hemlock stands (lower light and $\mathrm{pH}$ ) compared with red oak stands.

Light availability has previously been found to be an important determinant of seedling regeneration dynamics in temperate forests (Pacala et al. 1996, Finzi and Canham 2000), and a critical component of canopyseedling positive feedbacks in tropical forests (Torti et al. 2001), even when overall variability is relatively small (Walters and Reich 2000). Species show varying responses to changes in light availability, and these differences in response may drive the spatial and temporal course of succession (Pacala et al. 1994, Kobe et al. 1995, Bazzaz 1996). In the present experiment, we found that, for survival at least, species' responses to light availability could be predicted to some extent from their successional position. The most late successional species in the system (hemlock) was the only species whose survival did not respond positively in general to light availability. As light is a critical resource for all plants, the mechanistic basis for these light responses is relatively well established. In contrast, the physiological processes underlying seedling responses to changes in $\mathrm{pH}$ are less clear (Gough et al. 2000). It has long been hypothesized that soil $\mathrm{pH}$ plays a critical role in the development of landscape mosaics in mixed temperate forests (Daubenmire 1930), and more recently, soil $\mathrm{pH}$ has been shown to alter species' responses to light availability (Kobe 1996). Soil pH is not a resource sensu stricto (Bazzaz 1996), but rather controls the availability of a number of critical soil nutrients, such as phosphorus and many of the major cations (Marschner 1995). The mechanisms driving species' responses to changing soil $\mathrm{pH}$ need to be investigated further.

Our correlation approach was useful in identifying the main factors driving stand-level differences in seedling regeneration, but also highlighted a couple of limitations with the study. Light availability and $\mathrm{pH}$ were closely correlated to one another in the study, and so individual effects could not be separated further without any experimental manipulation (Catovsky and Bazzaz 2000). In addition, as the measurements were only conducted over three growing seasons, we might not have picked up effects mediated by longer-term soil changes, such as site fertility. Soil processes operate over longer time scales than light (Caldwell and Pearcy 1994), and so changes in soil characteristics following alteration of community composition will tend to lag changes in above-ground microclimate (Willis et al. 1997). Simulation models in such eastern North American mixed forests clearly demonstrate that soil nitrogen and water availability only control the dynamics of the canopy trees, while light exerts stronger control on seedling and sapling dynamics (Pastor and Post 1986). Nevertheless, of the major broad-leaved species in mixed temperate forests, red oak produces litter with the highest carbon to nitrogen ratio (i.e. closest to hemlock) (Finzi et al. 1998b), and so it is perhaps not too surprising that we did not see any significant effects of soil nitrogen availability on seedling regeneration between stand types.

\section{Importance of canopy-seedling feedbacks in temperate forests}

Feedbacks between stand composition and seedling regeneration are likely to play a critical role in the structure and dynamics of many forests containing a distinct landscape mosaic of stand types, in both temperate (Frelich et al. 1993) and tropical regions (Torti et al. 2001). Canopy-seedling feedbacks emphasize the importance of species' effects on their environment in controlling vegetation structure and dynamics, as first proposed by Clements (1916). In the present study, we have demonstrated that canopy-seedling feedbacks operate in both coniferous (hemlock dominated) and broad-leaved (red oak dominated) stands in mixed temperate forests, and we were able to determine both demographic and resource-based mechanisms underlying such feedbacks. Hemlock seedlings were favoured in hemlock stands (a true positive feedback), as a result of high seed inputs, high seedling emergence and relatively high seedling survival, while a suite of mid-successional species (including red oak, red maple, and birch) were favoured in red oak stands, through adequate seedling emergence and high overall seedling survival. Variation in both light availability and soil $\mathrm{pH}$ were the primary correlates of these stand-level differences in seedling regeneration patterns. In mixed temperate forests, these canopy-seedling feedbacks could act to slow successional trajectories and contribute to the maintenance of a stable landscape structure in the absence of a major disturbance.

Acknowledgements - We thank Chrissy Frederick, Joe LaCasse, and Henry Schumacher for assistance in the field. Richard Cobb, Steve Currie, Matt Kizlinski, and David Orwig at Harvard Forest provided tremendous help with the resin bag analysis, and Alison Magill, Gloria Quigley, and John Aber at the Complex Systems Research Group (Univ. of New Hampshire) were kind enough to assist with the buried bag soil analysis. We are very grateful to Guntram Bauer, Christine Muth, Eric Macklin, Amity Wilczek, Kristin Lewis, and Kristina Stinson, who all contributed substantially to the design and interpretation of the experiment, and to David Foster, John O'Keefe, and Glenn Motzkin, who were of invaluable assistance with locating study sites. Jonathan 
Levine, Tom Poulson, Bill Platt, Chris Peterson, and John Pastor all provided useful comments on the final draft of the paper. This work was supported by a NASA Earth System Science Graduate Fellowship, a Student Dissertation Grant from the Department of Organismic and Evolutionary Biology, and a Mellon Foundation Grant from Harvard Forest (all to S.C.), and by the Harvard Forest Long-Term Ecological Research Program (NSF Grant DEB 9411795 to F.A.B.).

\section{References}

Bartlett, R. M., Reader, R. J. and Larson, D. W. 1991. Multiple controls of cliff-edge distribution patterns of Thuja occidentalis and Acer saccharum at the stage of seedling recruitment. - J. Ecol. 79: 183-197.

Bazzaz, F. A. 1983. Characteristics of populations in relation to disturbance in natural and man-modified ecosystems. In: Mooney, H. A. and Godron, M. (eds), Disturbance and ecosystems. Springer-Verlag, pp. 259-275.

Bazzaz, F. A. 1996. Plants in changing environments: linking physiological, population, and community ecology. Cambridge Univ. Press.

Boettcher, S. E. and Kalisz, P. J. 1990. Single-tree influence on soil properties in the mountains of eastern Kentucky. Ecology 71: 1365-1372.

Burns, R. M. and Honkala, B. H. (eds) 1990. Silvics of North America: Volumes 1 and 2 (conifers and hardwoods). U.S. Dept of Agriculture.

Caldwell, M. M. and Pearcy, R. W. (eds) 1994. Exploitation of environmental heterogeneity by plants. - Academic Press.

Canham, C. D., Finzi, A. C. Pacala, S. W. and Burbank, D. H. 1994. Causes and consequences of resource heterogeneity in forests: interspecific variation in light transmission by canopy trees. - Can. J. For. Res. 24: 337-349.

Catovsky, S. and Bazzaz, F. A. 2000. The role of resource interactions and seedling regeneration in maintaining a positive feedback in hemlock stands. - J. Ecol. 88: 100112.

Clements, F. E. 1916. Plant succession: an analysis of the development of vegetation. - Carnegie Institution of Washington.

Collins, S. L. 1990. Habitat relationships and survivorship of tree seedlings in hemlock-hardwood forest. - Can. J. Bot. 68: $790-797$.

Connell, J. H. and Slatyer, R. O. 1977. Mechanisms of succession in natural communities and their role in community stability and organization. - Am. Nat. 111: 1119-1144.

Cornett, M. W., Reich, P. B. and Puettmann, K. J. 1997. Canopy feedbacks and microtopography regulate conifer seedling distribution in two Minnesota conifer-deciduous forests. - Écoscience 4: 353-364.

Daubenmire, R. F. 1930. The relation of certain ecological factors to the inhibition of forest floor herbs under hemlock. - Butler Univ. Botanical Studies 1: 61-76.

Davis, M. B., Calcote, R. R., Sugita, S. and Takahara, H. 1998. Patchy invasion and the origin of a hemlock-hardwoods forest mosaic. - Ecology 79: 2641-2659.

Davis, M. B., Sugita, S., Calcote, R. R. et al. 1994. Historical development of alternate communities in a hemlock-hardwood forest in northern Michigan, USA. - In: Edwards, P. J., May, R. M. and Webb, N. R. (eds), Large-scale ecology and conservation biology. Blackwell Scientific, pp. $19-39$.

Finzi, A. C. and Canham, C. D. 2000. Sapling growth in response to light and nitrogen availability in a southern New England forest. - Forest Ecol. Manag. 131: 153-165.

Finzi, A. C., Canham, C. D. and van Breemen, N. 1998a. Canopy tree-soil interactions within temperate forests: species effects on $\mathrm{pH}$ and cations. - Ecol. Appl. 8: 447-454.

Finzi, A. C., van Breemen, N. and Canham, C. D. 1998b. Canopy tree-soil interactions within temperate forests: spe- cies effects on soil carbon and nitrogen. - Ecol. Appl. 8: 440-446.

Forcier, L. K. 1975. Reproductive strategies and the co-occurrence of climax tree species. - Science 189: 808-810.

Foster, D. R. 1988. Species and stand response to catastrophic wind in central New England, USA. - J. Ecol. 76: 135151.

Foster, D. R., Motzkin, G. and Slater, B. 1998. Land-use history as long-term broad-scale disturbance: regional forest dynamics in central New England. - Ecosystems 1: 96-119.

Frelich, L. E. and Reich, P. B. 1999. Neighborhood effects, disturbance severity, and community stability in forests. Ecosystems 2: 151-166.

Frelich, L. E., Calcote, R. R., Davis, M. B. and Pastor, J. 1993. Patch formation and maintenance in an old-growth hemlock-hardwood forest. - Ecology 74: 513-527.

Friend, D. T. C. 1961. A simple method of measuring integrated light values in the field. - Ecology 42: 577-580.

Gibson, D. J. 1986. Spatial and temporal heterogeneity in soil nutrient supply measured using in situ ion-exchange resin bags. - Plant Soil 96: 445-450.

Godman, R. M. and Lancaster, K. 1990. Tsuga canadensis (L.) Carr. - In: Burns, R. M. and Honkala, B. H. (eds), Silvics of North America. Volume I: Conifers. U.S. Dept of Agriculture, pp. 604-612.

Gotelli, N. J. 1998. A primer of ecology, 2nd edn. - Sinauer.

Gough, L., Shaver, G. R., Carroll, J. et al. 2000. Vascular plant species richness in Alaskan arctic tundra: the importance of soil pH. - J. Ecol. 88: 54-66.

Hewitt, N. 1998. Seed size and shade-tolerance: a comparative analysis of North American temperate trees. - Oecologia 114: $432-440$.

Hiura, T. and Fujiwara, K. 1999. Density-dependence and co-existence of conifer and broad-leaved trees in a Japanese northern mixed forest. - J. Veg. Sci. 10: 843-850.

Horn, H. S. 1971. The adaptive geometry of trees. - Princeton Univ. Press.

Houle, G. 1994. Spatiotemporal patterns in the components of regeneration of four sympatric tree species-Acer rubrum, A.saccharum, Betula alleghaniensis and Fagus grandifolia. J. Ecol. 82: 39-53.

Hubbell, S. P. and Foster, R. B. 1986. Biology, chance, and history and the structure of tropical rain forest tree communities. - In: Diamond, J. and Case, T. J. (eds), Community ecology. Harper and Row, pp. 314-329.

Hubbell, S. P. Foster, R. B., O'Brien, S. T et al 1999. Light-gap disturbances, recruitment limitation, and tree diversity in a neotropical forest. - Science 283: 554-557.

Hughes, J. W., Fahey, T. J. and Browne, B. 1987. A better seed and litter trap. - Can. J. For. Res. 17: 1623-1624.

Kelty, M. J. 1986. Development patterns in two hemlockhardwood stands in southern New England. - Can. J. For. Res. 16: 885-891.

Kobe, R. K. 1996. Intraspecific variation in sapling mortality and growth predicts geographic variation in forest composition. - Ecol. Monogr. 66: 181-201.

Kobe, R. K., Pacala, S. W., Silander, J. A., Jr. and Canham, C. D. 1995. Juvenile tree survivorship as a component of shade tolerance. - Ecol. Appl. 5: 517-532.

Koenig, W. D. and Knops, J. M. H. 1998. Scale of mast-seeding and tree-ring growth. - Nature 396: 225-226.

Latham, R. E. 1992. Co-occurring tree species change rank in seedling performance with resources varied experimentally. - Ecology 73: 2129-2144.

Marschner, H. 1995. Mineral nutrition of higher plants, 2nd edn. - Academic Press.

Oliver, C. D. and Stephens, E. P. 1977. Reconstruction of a mixed-species forest in central New England. - Ecology 58: $562-572$.

Oosting, H. J. and Hess, D. W. 1956. Microclimate and a relic stand of Tsuga canadensis in the lower Piedmont in North Carolina. - Ecology 37: 28-39. 
Pacala, S. W., Canham, C. D., Silander, J. A., Jr. and Kobe, R. K. 1994. Sapling growth as a function of resources in a north temperate forest. - Can. J. For. Res. 24 2174-2183.

Pacala, S. W., Canham, C. D., Saponara, J. et al. 1996. Forest models defined by field measurements: estimation, error analysis and dynamics. - Ecol. Monogr. 66: 1-43.

Parent, S. and Messier, C. 1996. A simple and efficient method to estimate microsite light availability under a forest canopy. - Can. J. For. Res. 26: 151-154

Pastor, J. and Post, W. M. 1986. Influence of climate, soil moisture, and succession on forest carbon and nitrogen cycles. - Biogeochem. 2: 3-27.

Pastor, J. and Broschart, M. 1990. The spatial pattern of a northern conifer-hardwood landscape. - Landscape Ecol 4: $55-68$.

Pastor, J., Aber, J. D., McClaugherty, C. A. and Melillo, J. M. 1984. Aboveground production and $\mathrm{N}$ and $\mathrm{P}$ cycling along a nitrogen mineralization gradient on Blackhawk Island, Wisconsin. - Ecology 65: 256-268.

Petraitis, P. S. and Latham, R. E. 1999. The importance of scale in testing the origins of alternative community states. - Ecology 80: 429-442.

Poulson, T. L. and Platt, W. J. 1996. Replacement patterns of beech and sugar maple in Warren Woods, Michigan. Ecology 77: 1234-1253.

Raup, H. M. and Carlson, R. E. 1941. The history of land-use in the Harvard Forest. - Harvard For. Bull. 20: 1-64.

Ribbens, E., Silander, J. A., Jr. and Pacala, S. W. 1994 Seedling recruitment in forests: calibrating models to predict patterns of tree seedling dispersion. - Ecology 75 $1794-1806$.

Sokal, R. R. and Rohlf, F. J. 1995. Biometry, 3rd edn. - W. H. Freeman and Company.

Spurr, S. H. 1956. Forest associations in the Harvard Forest. - Ecol. Monogr. 26: 245-262.

Tilman, D. 1988. Plant strategies and the dynamics and structure of plant communities. - Princeton Univ. Press.
Torti, S. D., Coley, P. D. and Kursar, T. A. 2001. Causes and consequences of monodominance in tropical lowland forests. - Am. Nat. 157: 141-153.

van Breemen, N. and Finzi, A. C. 1998. Plant-soil interactions: ecological aspects and evolutionary implications. - Biogeochem. 42: 1-19.

Walters, M. B. and Reich, P. B. 1996. Are shade tolerance, survival, and growth linked? Low light and nitrogen effects on hardwood seedlings. - Ecology 77: 841-853.

Walters, M. B. and Reich, P. B. 2000. Seed size, nitrogen supply, and growth rate affect tree seedling survival in deep shade. - Ecology 81: 1887-1901.

Westveld, M. 1956. Natural forest vegetation zones of New England. - J. For. 54: 332-338.

Willis, K. J., Braun, M., Sümegi, P. and Tóth, A. 1997. Does soil change cause vegetation change or vice versa? A temporal perspective from Hungary. - Ecology 78: 740-750.

Wilson, J. B. and Agnew, A. D. Q. 1992. Positive-feedback switches in plant communities. - Adv. Ecol. Res. 23: 263-336.

Woods, K. D. 1979. Reciprocal replacement and the maintenance of codominance in a beech-maple forest. - Oikos 33: $31-39$.

Woods, K. D. 1984. Patterns of tree replacement: canopy effects on understory pattern in hemlock-northern hardwood forests. - Vegetatio 56: 87-107.

Woods, K. D. 2000a. Dynamics in late-successional hemlockhardwood forests over three decades. - Ecology 81: 110126.

Woods, K. D. 2000b. Long-term change and spatial pattern in a late-successional hemlock-northern hardwood forest. - J. Ecol. 88: 267-282.

Yorks, T. E., Leopold, D. J. and Raynal, D. J. 2000. Vascular plant propagule banks of six eastern hemlock stands in the Catskill Mountains of New York. - J. Torrey Bot. Soc. 127: $87-93$.

Yoshida, N. and Ohsawa, M. 1999. Seedling success of Tsuga sieboldii along a microtopographic gradient in a mixed cool-temperate forest in Japan. - Plant Ecol. 140: 89-98. 